\title{
ECOLOGY
}

\section{Spider species composition in the tree-shrub strata of riparian forests and its microhabitats in southern Brazil}

\author{
Everton N.L. Rodrigues ${ }^{1 *}$, Patrícia E.S. Rodrigues ${ }^{2} \&$ Milton de S. Mendonça Jr ${ }^{3}$
}

\begin{abstract}
'Laboratório de Diversidade e Sistemática de Arachnida, Programa de Pós-Graduação em Biologia, Universidade do Vale do Rio dos Sinos. Avenida Unisinos 950, 93022-000 São Leopoldo, RS, Brazil.

2 Programa de Pós-Graduação em Biologia Animal, Universidade Federal do Rio Grande do Sul. Avenida Bento Gonçalves 9500, Bloco IV, Prédio 43435, 91501-970 Porto Alegre, RS, Brazil.

${ }^{3}$ Departamento de Ecologia, Instituto de Biociências, Universidade Federal do Rio Grande do Sul. Avenida Bento Gonçalves 9500, Bloco IV, Prédio 43422, 91501-970 Porto Alegre, RS, Brazil.

‘Corresponding author. E-mail: enlrodrigues@unisinos.br
\end{abstract}

\begin{abstract}
The composition of the spider fauna of riparian forests is insufficiently known. These forests, adjacent to both aquatic and terrestrial environments, are recognised as having important ecosystem functions. We compare the composition of spider assemblages of four riparian forests in different drainage basins, along with their microhabitats (edges and forest interior), in the state of Rio Grande do Sul, southern Brazil. Sampling was carried out in the riparian forests of the following rivers: Piratini, municipality of Arroio Grande; Camaquã, municipality of Cristal; Sinos, municipality of Parobé, and Maquiné, municipality of Maquiné. Two samples per season were collected in two years, by sampling the tree-shrub strata with a beating tray, following fixed transects. There were six transects per drainage basin, two per microhabitat: grassland edge, forest interior and river edge. Overall, 42,057 spiders were sampled (juveniles: $79 \%$; adults: $21 \%)$. Among the adults (8,851 individuals), we identified 440 species. Similarity analyses (ANOSIM) indicated that the araneofauna composition of the four drainage basins differ in their quantitative (Morisita) and qualitative (Simpson) similarity indexes. There were no differences in composition among microhabitats. The composition of the Maquiné River basin was the most distinct, possibly due to a greater influence of the Atlantic forest on it and a greater dominance of the Linyphiidae Sphecozone personata (Simon, 1894) (SIMPER analysis, contribution to dissimilarity: $12.15 \%$ ). Differences in spider composition on large spatial scales most likely reflect regional variations in a number of environmental factors, and result in each area having in increased importance in terms of conservation.
\end{abstract}

KEY WORDS. Spider assemblage, beating tray, ordination, microhabitats, riparian forest.

The fact that spiders are widely distributed in terrestrial ecosystems makes them efficient organisms to help elucidate biodiversity patterns (Uetz 1991, Foelix 1996, Platnick 1999, CaRDoso 2009). In order to know and to catalogue the biodiversity elements of a given place, however, it is necessary to conduct biodiversity surveys (DENNIs \& RUGGIERo 1996). Such inventories should not be restricted to a list of species, but need to include information on systematics, ecology, and biogeography (HALFFTER et al. 2001).

Among the environments where spiders have already been inventoried, riparian forests are still largely unknown (RoDRIGUES et al. 2014). These habitats have important ecosystem functions, since they are ecotones between adjacent environments and therefore harbor a diverse fauna (NAIMAN et al. 1993). Riparian forests are peculiar: they occupy a small proportion of the hydrographic basin they belong to, are considered ecologically stable and are well defined, have high plant biomass production and support high biodiversity levels compared to other forest environments (DAvide \& Botelho 1999). They are considered extremely important for plant dispersal, and as "corridors" for animal movement (NAIMAN et al. 1993, MALAVASI et al. 2004), including spiders (RAIzer et al. 2005, Rodrigues et al. 2014). However, these corridors may be interrupted when plant formations are altered. In the past, Brazilian native riparian forests were partly substituted for large plantations of exotic trees and, very close to rivers, by agricultural endeavors, a process that has resulted in numerous forest remnants and semi-natural areas (DENNIS 1997, Malavasi et al. 2004). 
Understanding the composition of spider species and their distribution within riparian forests is the first step to increasing our knowledge on the dynamics of spider assemblages. This information may be helpful in planning environmental monitoring, and ultimately improving the conservation of these forest formations. Data on the spider fauna of the native areas of southern Brazil have increased through simple species lists and ecological studies (Indrusiak \& Kotzian 1998, Bonaldo \& Ott 2002, Rodrigues 2005, Silva \& Araújo 2005, OtT et al. 2006, Bonaldo et al. 2007, Podgaiski et al. 2007, BALdissera et al. 2008, Rodrigues \& Mendonça, 2012, Rodrigues et al. 2014). However, there are still few studies comparing species composition among different ecosystems.

There are a number of factors determining the species composition of spider assemblages (Uetz 1991, Foelix 1996). For example, human impacts, which lead to edge effects in forests (Murcia 1995), and changes in abiotic factors (BALDISSERA et al. 2008) may force spiders to live in a more open environment where sun light, temperature, humidity and other factors are different than the conditions they are adapted to (RoDRIGUEs et al. 2014). Spiders are known to be strongly influenced by habitat structure (Uetz 1991, Gallér \& Schwéger 2014), including vegetation structure (Wu \& Cheng 2012, Rodrigues et al. 2014) and microclimatic factors (SAMU et al. 1999). In this work we compare the spider assemblages of three distinct microhabitats (edges: river edge and grassland edge; and forest interior) and four distinct drainage basins of a riparian forest of the state of Rio Grande do Sul, southern Brazil. We also give a list of the spider species found in these riparian forests.

\section{MATERIAL AND METHODS}

Sampling took place in four riparian forests on four distinct drainage basins in southern Brazil, state of Rio Grande do Sul (RS) (Fig. 1). Detailed information on these basins can be found in Rodrigues \& MENDONÇA (2012). Their main characteristics are: 1) Piratini River (PR), sampling site at the municipality of Arroio Grande ( $31^{\circ} 54^{\prime} 06.47^{\prime \prime}$ S, 52 $\left.39^{\prime} 08.29^{\prime \prime} \mathrm{W}\right), 14 \mathrm{~m}$ a.s.l., good state of conservation, largest continuous native forest segment in the coastal plain region, climate TE UM "humid temperate" (MAluf 2000); 2) Camaquã River (CR), sampling site at the municipality of Cristal $\left(31^{\circ} 01^{\prime} 01.7^{\prime \prime} \mathrm{S}, 51^{\circ} 56^{\prime} 42.0^{\prime \prime} \mathrm{W}\right), 14 \mathrm{~m}$ a.s.l., good state of conservation, continuous forest at the centre-south part of the Coastal Plain region, climate STE UM "humid subtemperate" (Maluf 2000); Sinos River (SR), sampling site at the municipality of Parobé (2941'06.94”S, 5051'05.98”W), 6-10 m a.s.l., fragmented forest in the Serra Geral slopes region, sampling site at the largest fragment available, climate ST SB "sub-humid subtropical" (Maluf 2000); Maquiné River (MR), sampling site at the municipality of Maquiné (29 40'47.99"S, 50¹1'20.03"W), between the Serra Geral slopes and the Coastal Plain, belongs to Atlantic forest Biosphere Reserve recognized by UNESCO, climate is ST PU "perhumid subtropical" (MALUf 2000).

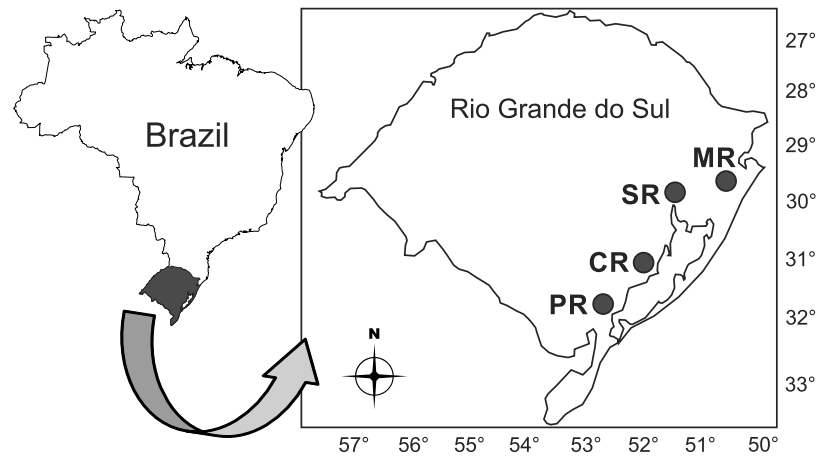

Figure 1. Schematic map of Brazil and detail of state of Rio Grande do Sul with riparian forests sampled. (PR) Piratini river, (CR) Camaquã river, (SR) Sinos river, (MR) Maquiné river.

Fieldwork lasted two years (August $1^{\text {st }}, 2007$ to June $6^{\text {th }}$, 2009), with two samplings per season (four seasons: spring, summer, autumn and winter) at each of the four drainage basins, totaling 64 samples overall, thus covering distinct times of the year, differences in vegetation (e.g., plant phenology) and climatic variability (temperature, rainfall, river levels). To evaluate spider fauna diversity we used six transects (approximately $30 \mathrm{~m}$ each) per sampling site, straight $4 \mathrm{~m}$-wide lines, parallel to the river. These were placed in different microhabitats at each forest site: two transects at the forest edge with the river (river edge, RE); two transects at the forest interior (FI) and the latter two at the forest edge with neighboring grasslands (grassland edge, GE). Transects at the same microhabitat were placed at least $500 \mathrm{~m}$ far from each other. Overall, 24 transects were thus established on all forest sites.

The method employed for spider capture was the beating tray (BT), which allows access to tall herbs, small and medium-sized shrubs, small trees and large tree branches, along with woody vines (Coddington et al. 1996, IndRusiak \& KotZian 1998, Sørensen et al. 2002). On each transect, spiders were sampled for $45 \mathrm{~min}$ with a $70 \mathrm{~cm} \times 70 \mathrm{~cm}$ BT with white nylon fabric, totaling $288 \mathrm{~h}$ of sampling. Collecting was carried out by the first and second authors.

Spiders were kept in vials and preserved in ethanol $80 \%$. The material was identified by the first author in the Laboratorio de Aracnologia and the material was deposited in the spider collection of the Museu de Ciências Naturais, in the Fundação Zoobotânica do Rio Grande do Sul, Porto Alegre, Brazil (MCN/ FZB, curator: Ricardo Ott).

The species composition of the four distinct localities and the three microhabitats were compared with separate ANOSIM tests (Clarke \& WARWick 1994). The null hypotheses are that there are no differences in species composition in space in a larger scale, among drainage basins, and that there are no differences in space in a smaller scale, among microhabitats. Two tests were employed per factor, each with a different similarity index, one qualitative (Simpson) and one quantitative (Morisita). 
With the same composition matrix we plotted two ordinations (non-metric multidimensional scaling, NMDS), one for each of the previously mentioned indexes. For each ordination we also obtained stress values, measuring the relationship between real distances, obtained with dissimilarity indexes between samples, with distances used in the NMDS.

A SIMPER (Similarity percentage) analysis was employed to evaluate which species contributed more to the dissimilarity (Bray Curtis index) among basins and microhabitats (ClARKE \& WARWICK 1994). All analyses were implemented in PAST (Paleontological Statistics, HAMMER \& HARPER 2009).

\section{RESULTS}

Overall, 42,057 spiders were collected, representing 35 families. For the purpose of analysis, only adults were considered, since immature spiders are difficult to identity to species. However, immatures predominated in the inventory, representing $79 \%$ of all specimens captured. The total sample contained 8,851 adult spiders (21\%), representing 29 families (Appendix 1), and females were more abundant (60.8\%) than males $(39.2 \%)$.

\section{Family composition among basins and microhabitats}

Only juvenile spiders represented the following families in our samples: Ctenidae, Hersiliidae, Idiopidae, Lycosidae, Pisauridae and Segestriidae. Among the families that were represented by adults, Theridiidae predominated ( $\mathrm{n}=4,363$ individuals, $49.3 \%$ of the total), followed by Linyphiidae (1,646, 18.6\%), Salticidae $(742,8.4 \%)$, Araneidae $(533,6.1 \%)$ and Thomisidae $(265,3 \%)$, which together comprised $85 \%$ of all spiders.

The riparian forest of the Maquiné River basin had the greatest number of families (25), followed by Camaquã and Sinos (21 families each), with the Piratini River scoring only 20 families. Five families were only found at the Maquiné River (Clubionidae, Hahniidae, Gnaphosidae, Scytodiidae and Synotaxidae) and one at the Piratini River (Dictynidae). Sixteen families were shared among distinct basins. Theridiidae was the most abundant family, with more than $50 \%$ of the sampled spiders in each basin, except for the Maquiné River basin, where Linyphiidae dominated.

The family composition of adults was very similar among microhabitats, with 25 families at each edge (river and grassland) and 24 families at the forest interior. Theridiidae was again the predominant family in all microhabitats, followed by Linyphiidae. The three microhabitats shared 22 families, with one exclusive family at each one (RE: Clubionidae, FI: Gnaphosidae, GE: Dictynidae, Appendix 1).

\section{Species list and composition among basins and microhabitats}

Overall there were 440 spider species/morphospecies, in 168 genera. A total of 232 named species were obtained, representing $53 \%$ of all adults. The other $47 \%$ of the specimens could not be identified. They were separated into morphospe- cies, and we believe that at least some of them might represent undescribed species (Appendix 1). Acragas nigromaculatus (Mello-Leitão, 1922), Cylistella cuprea (Simon, 1864), Faiditus alticeps (Keyserling, 1891), Lyssomanes leucomelas Mello-Leitão, 1917, Mopiopia labyrinthea (Mello-Leitão, 1947), Opas paranensis (Mello-Leitão, 1937), Runcinioides argenteus Mello-Leitão, 1929, Sanogasta maculosa (Nicolet, 1849), Stephanopsis colatinae Soares \& Soares, 1946, Synema nigrianum Mello-Leitão, 1929 and Trogloneta cantareira Brescovit \& Lopardo, 2008 are recorded for the first time for the state of Rio Grande do Sul and Conifaber yasi Grismado, 2004, Deinopis amica Schiapelli \& Gerschman, 1957 and Senoculus purpureus (Simon, 1880) are new records for Brazil. Among the most common families, Araneidae and Theridiidae had the highest percentages of named spider species (95.3\% and $64.7 \%$, respectively), which is an indication that the taxonomy of these two families in southern Brazil is well known.

Amaurobiidae, Clubionidae, Dictynidae, Gnaphosidae, Hahniidae, Mysmenidae, Nephiliidae, Scytodiidae and Synotaxidae were each represented by a single species, as follows: Hahnia sp. (Hahnidae), Scytodes maquine Rheims \& Brescovit, 2009, and Synotaxus longicaudatus (Keyserling, 1891) (Synotaxidae), were only found at the Maquiné River basin; Elaver brevipes (Keyserling, 1891) (Clubionidae), Dictynidae undetermined (Dictynidae), and Zimiromus montenegro Buckup \& Brescovit, 1993 (Gnaphosidae) were singletons. All other families had more than one individual and were registered at more than one basin (Appendix 1).

Of all species/morphospecies, 47 (10.68\%) were shared among all basins, 64 (14.54\%) were shared at least among three basins, 104 (23.64\%) were shared between at least two basins, and most (225 species, $51.14 \%$ ) were exclusive to a single basin. Riparian forests of the Piratini and Camaquã basins had the greatest number of shared species (34 species), the smallest being between Piratini and Maquiné (9). The greatest number of exclusive species was recorded at the Maquiné basin (82 species) and the fewest number of exclusives at Sinos basin (38); the forests at Piratini and Camaquã had nearly the same number of exclusive species (55 and 50, respectively).

The most abundant species was Sphecozone personata (Simon, 1894) ( $\mathrm{n}=1,222,13.8 \%$ of the total), but it was almost exclusive to the Maquiné River basin, except for two individuals found at Sinos basin. The second most abundant species, Thymoites promatensis Lise \& Silva, 2009 ( $\mathrm{n}=$ 436, 4.93\%) was recorded in all rivers except Maquiné, and the third most abundant, Spintharus gracilis Keyserling, 1886 ( $\mathrm{n}=325,3.67 \%)$ was sampled from all basins except Piratini (Appendix 1).

Among the spider species for which more than 100 individuals were collected ( 22 species), or which represented more than $1 \%$ of the total, nine were not found at all rivers. Some of those were sampled from only one or two of the basins (Appendix 1).

Among all microhabitats, 127 species (28.86\% of the total) were shared, $129(29.32 \%)$ were shared between at least two, and 184 species (41.82\%) were exclusive to one microhabitat (Appendix 1). The greatest number of shared species was found 
between the edges (river edge and grassland edge: 63 species) and the greater number of exclusive species occurred at the edge of the grassland (75 species), followed by the river edge (56) and forest interior (53). Of the four most abundant species, equivalent to more than $25 \%$ of the total, all were predominant in the forest interior, each with almost $50 \%$ of all individuals recorded there. Thymoites promatensis was more dominant in the forest interior $(>88 \%)$.

\section{Araneofauna composition quantitative similarity and dissimilarity}

The quantitative (Morisita, ANOSIM: $\mathrm{R}=0.824, \mathrm{p}<0.0001$ ) and qualitative indexes (Simpson, ANOSIM: $\mathrm{R}=0.809, \mathrm{p}=0.001$ ) in our results indicate that the spider fauna differ significantly among river basins. The SIMPER analysis reveals that Sphecozone personata contributed a much greater value (12.15) than the other species (Table 1) when it comes to quantitative differences among river basins. The first ten species, all contributing more than $1 \%$, together contribute $38 \%$ of the total dissimilarity among rivers.

Table 1. SIMPER analysis for the ten spiders species contributing most to dissimilarity among riparian forests in southern Brazil. 'Species percentage contribution to dissimilarity, ${ }^{2}$ cumulative dissimilarity among riparian forests, ${ }^{3}$ average species abundance in each riparian forest.

\begin{tabular}{lccrrrrr}
\hline \multirow{2}{*}{ Species } & Contribution ${ }^{1} \begin{array}{c}\text { Cumulative } \\
\text { (\%) }\end{array}$ & \multicolumn{4}{c}{ Average species abundance $^{3}$} \\
\cline { 5 - 8 } & & Piratini & Camaquã & Sinos & Maquiné \\
\hline Sphecozone personata & 12.150 & 15.61 & 0.00 & 0.0 & 0.667 & 407.00 \\
Thymoites promatensis & 3.992 & 20.73 & 4.33 & 45.0 & 96.000 & 0.00 \\
Spintharus gracilis & 2.774 & 24.30 & 0.00 & 3.0 & 33.000 & 72.30 \\
Hetschkia gracilis & 2.135 & 27.04 & 10.30 & 45.3 & 1.000 & 43.30 \\
Theridion calcynatum & 1.854 & 29.42 & 44.00 & 22.0 & 0.000 & 0.00 \\
Wamba crispulus & 1.845 & 31.79 & 43.00 & 33.0 & 10.000 & 3.33 \\
Phycosoma alta & 1.452 & 33.65 & 21.70 & 18.3 & 26.300 & 0.00 \\
Phoroncidia reimoseri & 1.296 & 35.32 & 0.00 & 2.0 & 35.300 & 9.00 \\
Metagonia sp. & 1.161 & 36.81 & 0.00 & 18.7 & 0.000 & 28.00 \\
Mangora strenua & 1.148 & 38.28 & 29.00 & 10.0 & 3.330 & 2.33 \\
\hline Average dissimilaity & & & & & &
\end{tabular}

Average dissimilarity overall: 77.86

Results of the multivariate analysis (NMDS) revealed a proximity between the Piratini and Camaquã rivers, both in the qualitative (stress: 0,166) (Fig. 2) and quantitative (stress: 0,126) (Fig. 3) indexes, but a larger distance was revealed for the Maquiné River. The Sinos River is at the threshold between the Piratini-Camaquã and Maquiné rivers. With respect to the qualitative index, it is possible that the Maquiné River is more distinct due to the elevated number of adult spiders of the family Linyphiidae, since Theridiidae adults predominated at all other basins. In the qualitative index, the Maquiné River basin formed an isolated cluster, most likely due to the high number of exclusive species. At the different microhabitats, species composition was not significantly distinct, neither according to quantitative (Morisita, ANOSIM: $\mathrm{R}=-0.078, \mathrm{p}=0.709$, Fig. 4), nor qualitative indicators (Simpson, $\mathrm{R}=0.008, \mathrm{p}=0.442$, Fig. 5). The NMDS ordination had stress values close to the ones reported above: 0.127 for Morisita (Fig. 4) and 0.165 for Simpson (Fig. 5).

In the SIMPER analysis for microhabitats (Table 2), species contributing the most were the same as for the basins analysis (S. personata, T. promatensis, $S$. gracilis), with greater values at the forest interior. The ten species in Table 2 contributed more than $36 \%$ to the dissimilarity among microhabitats. At basins as well as in microhabitats, among these first ten species with the highest contribution, seven belong to Theridiidae.

Table 2. SIMPER analysis for the ten spiders species contributing most to dissimilarity among microhabitats of riparian forests in southern Brazil. 'Species percentage contribution to dissimilarity, ${ }^{2}$ cumulative dissimilarity among microhabitat, ${ }^{3}$ average species abundance in each microhabitat.

\begin{tabular}{|c|c|c|c|c|c|}
\hline \multirow[b]{2}{*}{ Species } & \multirow{2}{*}{ Contribution ${ }^{1}$} & \multirow{2}{*}{$\begin{array}{c}\text { Cumulative }{ }^{2} \\
\text { (\%) }\end{array}$} & \multicolumn{3}{|c|}{ Average species abundance ${ }^{3}$} \\
\hline & & & $\begin{array}{c}\text { Grassland } \\
\text { edge }\end{array}$ & $\begin{array}{l}\text { River } \\
\text { edge }\end{array}$ & $\begin{array}{c}\text { Forest } \\
\text { interior }\end{array}$ \\
\hline Sphecozone personata & 9.677 & 13.03 & 82.50 & 73.30 & 150.0 \\
\hline Thymoites promatensis & 4.528 & 19.13 & 8.25 & 4.25 & 96.5 \\
\hline Spintharus gracilis & 2.319 & 22.25 & 16.00 & 29.50 & 35.8 \\
\hline Hetschkia gracilis & 1.909 & 24.82 & 23.80 & 13.00 & 38.3 \\
\hline Wamba crispulus & 1.635 & 27.03 & 26.30 & 20.80 & 20.0 \\
\hline Theridion calcynatum & 1.498 & 29.04 & 17.00 & 15.30 & 17.3 \\
\hline Phycosoma alta & 1.412 & 30.94 & 20.80 & 9.50 & 19.5 \\
\hline Phoroncidia reimoseri & 1.352 & 32.77 & 1.25 & 7.00 & 26.5 \\
\hline Mangora strenua & 1.231 & 34.42 & 2.50 & 5.75 & 25.3 \\
\hline Miagrammopes sp. 1 & 1.181 & 36.01 & 1.00 & 8.50 & 25.5 \\
\hline
\end{tabular}

Average dissimilarity overall: 74.26

\section{DISCUSSION}

In the present study, immature spiders predominated. The percentage of juvenile spiders sampled in the tropics and subtropics is usually about 60-70\% (SILVA 1996, SøRENSEN et al. 2002). The percentage we report here is close to that obtained by other authors using BT in southern (RoDRIGUEs 2005: 27.2\% adults, Bonaldo et al. 2007: 32.6\%, BALDISSERA et al. 2008: 15\%), south-eastern (GonÇALVES-SouZA et al. 2007: 18\%), west-central (RAizer et al. 2005: 28\%) and north-eastern Brazil (Oliveira-Alves et al. 2005: 29\%).

The predominance for Theridiidae in our samples was expected, in view of the sampling method. Members of this family are usually among the most species rich and abundant spiders in the tree-shrub strata, in inventories in southern Brazil (Rodrigues 2005, Silva \& Araújo 2005, Ott et al. 2006, Baldissera et al. 2008) and in riparian forests and similar areas (BonALDo et al. 2007). However, in a study comparing samples collected with BT at Turvo State Park (north-western portion of the state 

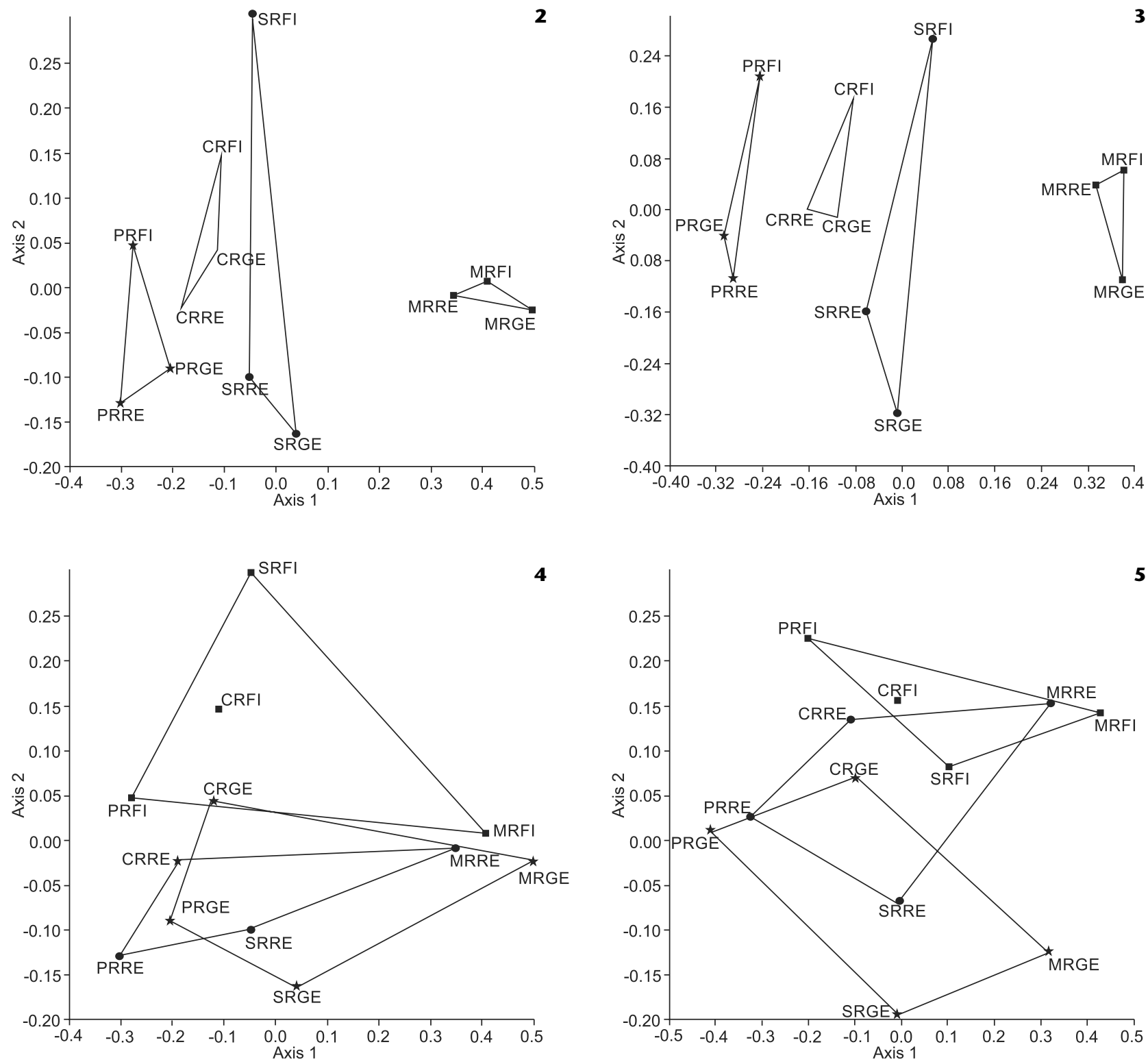

Figures 2-5. Non-metric multidimensional scaling (NMDS) of spider fauna composition in southern Brazil. (2-3) Among riparian forests: (2) Morisita index (stress: 0.166); (3) Simpson index (stress: 0.126). (4-5) Among microhabitats: (4) Morisita index (stress: 0.127); (5) Simpson index (stress: 0.165). (PR) Piratini river, (CR) Camaquã river, (SR) Sinos river, (MR) Maquiné river, (GE) grassland edge, (RE) river edge, (FI) forest interior.

of Rio Grande do Sul (RS)), Salticidae predominated in an area of continuous forest, (PODGAISK et al. (2007). All families recorded by previous studies in other ecosystems of RS, using the same sampling method we used, were also collected in riparian forests, with a few exceptions. Hersiliidae, recorded by INDRUSIAK \& KoTZIAN (1998) from the central portion of the state, was represented only by immature spiders in our samples. BonALDo et al. (2007) sampled Caponiidae and Selenopidae in different ecosystems, including a few riparian forests. PODGAISKI et al. (2007), using BT, obtained only immatures of Ctenidae, Lycosidae and Pisauridae in riparian forests. Отт et al. (2006) recorded Ctenidae, Lycosidae and Pisauridae only with other sampling methods, not BT, and observed that these families are nocturnal. In the west-central region of Brazil, state of Mato Grosso, RAIzER et al. (2005) studied the araneofauna of distinct environments, including various riparian forests of the Paraguay River, and recorded Araneidae 
as dominant. The family and species composition in our results are very different from theirs. This is possibly due to the fact that RAIZER et al. (2005) used nocturnal searching as a sampling method, which favors the capture of Araneidae spiders.The family composition of spiders represented by adults in our samples varied very little among microhabitats. Theridiidae predominated in all, followed by Linyphiidae. Both are found in the forest interior. Theridiids are known to occupy a variety of ecological niches (SiLVA 1996, SiLVA \& CoDdingTon 1996), which could possibly explain their wide distribution across microhabitats in our data.

The frequency of individuals of some families was higher in the forest interior than in the forest edges (e.g., Anyphaenidae, Linyphiidae, Mimetidae, Pholcidae, Theridiosomatidae). The great presence of Theridiosomatidae there substantiates the results of CODDINGTON (1986), according to whom these spiders inhabit mainly dark and humid sites within forests. At the Maquiné River, the river edge has a much more closed forest with high vegetation density. GonÇALVEs-SouzA et al. (2007) also found more Theridiosomatidae in the forest interior than at the forest edges of the Atlantic forest of south-eastern Brazil, also recording Linyphiidae with many species exclusive to the forest interior.

Members of Salticidae showed no clear microhabitat preference in our samples. In contrast, in previous studies this family was collected more often at the edges of forests (GonÇALVES-SouzA et al. 2007, Oliveira-Alves et al. 2005). These spiders have great visual accuracy, and can use the light incidence at the forest edges to locate and capture prey (RoMERo \& VASCONCELLOS-NeTO 2005).

Two families represented in our samples have been infrequently collected as part of other inventories in the South. Mysmenidae was represented by $T$. cantareira. Synotaxidae, represented by $S$. longicaudatus, had only been recorded from Rio Gande do Sul before by Silva \& Araújo (2005) having also been found in the Atlantic forest of south-eastern Brazil (GonçALVEs-Souza et al. 2007).

Besides the high species richness recorded in the present study, and new records for Rio Grande do Sul and Brazil, new species and new records had been previously reported from the same data by Rodrigues \& Mendonça (2011) for Araneidae; RoDrigues \& Marques (2010) for Phoroncidia (Theridiidae), Rodrigues \& Oтт (2010) for Psilocymbium (Linyphiidae) and Rodrigues \& BRESCOVIT (2015) for Thymoites (Theridiidae).

The composition of spider species differed among river basins. A number of factors such as geographical distance between basins, composition of the vegetation, climatic factors and biome may be plausible explanations for it. Piratini and Camaquã, which are very similar to each other, are within the Pampa biome. Given that the Maquiné River Basin is well within the Atlantic forest, it was expected that its fauna would differ from the other basins. The Atlantic forest is a peculiar biome, with high diversity levels and heterogeneous areas and habitats that reflect different physical environmental characteristics (Conservation International et al. 2000, Tabarelli et al. 2005).
Habitat heterogeneity could be responsible for the number of exclusive spider species at the Maquiné River basin. The Sinos River is at the limit between the Pampa and the Atlantic forest biomes. Even though the forest of the Sinos River is not continuous, our sampling site includes a fraction of the forest that is in good condition. These characteristics of the Sinos basin may explain the faunistic differences with respect to Maquiné.

Even though some species seemed to prefer one of the three forest microhabitats, and the slight tendency for edge microhabitats to share more species, the overall species composition did not significantly differ among them. In contrast, the results of OLIVEIRA-Alves et al. (2005), which were obtained with the same collecting method as ours, indicated low similarity between the spider fauna of the forest interior and the edges of an Atlantic forest fragment in north-eastern Brazil. They suggested that the faunistic differences in spider assemblages were due to the differences in vegetation at the edges and forest interior. When different environments are compared, variations in species composition are usually stronger.

An alternative explanation to vegetation structure determining faunistic differences is that the basins rest on different phytogeographic regions, thus supporting different plant species/taxa. This would affect spiders more strongly, and in a different way, than vegetation structure per se (RoDRIGUEs et al. 2014). Spider assemblages can be notably dependent on regional aspects, and dissimilarities among basins might indicate an association between spiders and particular vegetation subtypes (Raizer et al. 2005, Rinaldi \& Trinca 2008). A second possibility would be differences in the conservation status of the landscape of each basin, making it difficult to compare them. However, our data on vegetation density and complexity (not shown, partial results in RodRIGUES \& MENDONÇA 2012) in these riparian forests of Rio Grande do Sul do not support that the sampled riparian forests are similar in structure and density.

We had already shown that vegetation structure does not affect spider functional diversity: guild abundance and distribution in these same riparian forests do not respond to standard measurements of vegetation structure and density (RoDRIGUES \& Mendonça 2012). Now we can make a stronger case for this argument, since in our results the three microhabitats do not differ in their spider assemblages.

The richness of the riparian forests and their distinct spider composition among river basins adds weight to the view that these forests are very diversified, and that they need more thorough scientific exploration. A better understanding the role of riparian forests as faunal corridors and their relationship with nearby continuous forests could help subsidize their conservation and consequently the persistence of their functions in maintaining biodiversity. Differences in spider composition in a large spatial scale probably reflect regional variations in a series of environmental factors, also leading to a high conservation value for the riparian forests of each drainage basin, each having a distinct spider fauna. 


\section{ACKNOWLEDGEMENTS}

We thank José V. Feltrim for access to the study area at the Maquiné River; the people in Corticeiras Empreendimentos e Participações LTDA farm, in Cristal, for access to the study area and Tiago C. de Marchi and João A. Jarenkow for information on the areas; Erica H. Buckup, Maria Aparecida de L. Marques and Ricardo Ott for access to the spider collection and literature of the MCN. We also thank Pedro Cardoso (Finnish Museum of Natural History, Helsinki, Finland) and two anonymous reviewers for their valuable comments. CNPq funded ENLR through a PhD stipend 140586/2007-5). MMJ was supported by a research productivity grant (CNPq 309348/2012-9).

\section{LITERATURED CITED}

Baldissera R, Ganade G, Brescovit AD, Hartz SM (2008) Landscape mosaic of Araucaria forest and forest monoculture influencing understory spider assemblages in southern Brazil. Austral Ecology 33: 45-54. doi: 10.1111/j.1442-9993.2007.01789.x

Bonaldo AB, Otт R (2002) Aranhas, as versáteis estrategistas do Delta. Natureza em Revista 13: 40-43.

Bonaldo AB, Marques MAL, Pinto-da-Rocha R, Gardner T (2007) Species richness and community structure of arboreal spider assemblages in fragments of three vegetacional types at Banhado Grande wet plain, Gravataí river, Rio Grande do Sul, Brazil. Iheringia, Série Zoologia, 97: 143-151.

Cardoso P (2009) Standardization and optimization of arthropod inventories - the case of Iberian spiders. Biodiversity and Conservation 18: 3949-3962. doi: 10.1007/s10531-0099690-7

CodDington JA (1986) The genera of the spider family Theridiosomatidae. Smithsonian Contribution to Zoology 422: 1-96.

Coddington JA, Young LH, Coyle FA (1996) Estimating spider species richness in a Southern Appalachian cove hardwood forest. Journal of Arachnology 24: 111-128.

Conservation International do Brazil, Fundação SOS Mata Atlântica, Fundação Biodiversitas, Instituto de Pesquisas Ecológicas, Secretaria do Meio Ambiente do Estado de São Paulo, SEMAd/ Instituto Estadual de Florestas MG (2000) Avaliações e ações prioritárias para a conservação da biodiversidade da Mata Atlântica e Campos Sulinos. Brasília, Ministério do Meio Ambiente/SBF, 40p.

Clarke KR, Warwick RM (1994) Change in Marine Communities. Plymouth, National Research Concil, 144p.

Davide AC, Botelho SA (1999) Análise crítica dos programas de recomposição de matas ciliares em Minas Gerais, p. 172-188. In: Simpósio de Mata Ciliar: Ciência e Tecnologia. Belo Horizonte, Lavras, UFLA/FAEPE/CEMIG.

DenNis JG, Ruggiero MA (1996) Biodiversity inventory: building an inventory at scales from local to global, p. 149-156. In: Szaro RC, Johnston DW (Eds.) Biodiversity in managed landscapes. Oxford, Oxford University Press.
DeNNIS P (1997) Impact of forest and woodland structure on insect abundance and diversity, p. 321-349. In: WATT AD, STOCK NE, HunTER MD (Eds.). Forest and Insects. London, Chapman \& Hall.

Foelix RF (1996) Biology of spiders. New York, Oxford University Press, 306p.

GALlér R, SCHWÉGER S (2014) Habitat and landscape attributes influencing spider assemblages at lowland forest river valley (Hungary). North-Western Journal of Zoology 10: 36-41.

Gonçalves-Souza T, Matallana G, Brescovit AD (2007) Effects of habitat fragmentation on the spider community (Arachnida, Araneae) in three Atlantic forest remnants in Southeastern Brazil. Revista Ibérica de Aracnología 16: 35-42.

Halffter G, Moreno CE, Pineda EO (2001) Manual para evaluación de la biodiversidad en Reservas de la Biosfera. México, Cyted Orcyt, Unesco, Sea, 79p.

Hammer O, Harper DAT (2009) Past: Paleontological Statistics. Version 1.97. Available online at http://folk.uio.no/ohammer/past [Accessed: 16/05/2015]

INDRUSIAK LF, KOTZIAN CB (1998) Inventário das aranhas arborícolas de três regiões de Santa Maria, RS, Brazil. Revista Ciência e Natura 20: 187-214.

Malavasi UC, Malavasi MM, CuRTI M (2004) III Simpósio regional de mata Ciliar. Cascavel, Unioeste, 96p.

Maluf JRT (2000) Nova classificação climática do Estado do Rio Grande do Sul. Revista Brasileira de Agrometeorologia 8: $141-150$

MurCia C (1995) Edge effect in fragmented forests: implications for conservation. Trends in Ecology \& Evolution 10: 58-62.

Naiman RJ, Decamps H, Pollock M (1993) The role of riparian corridors in maitaning regional biodiversity. Ecological Applications 3: 209-212.

Oliveira-Alves A, Peres MCl, Dias MA, Cazais-Ferreira GS, Souto LRA (2005) Estudos das comunidades de aranhas (Arachnida: Araneae) em ambiente de Mata Atlântica no Parque Metropolitano de Pituaçu - PMP, Salvador, Bahia. Biota Neotropica 5: http://www.biotaneotropica.org.br/v5n1a/ pt/abstract?inventory+BN006051a2005

Otт R, Buckup EH, Marques MAL (2006) Aranhas, p. 172-184. In: Becker FG, Ramos RA, Moura LA (Orgs). Biodiversidade. Regiões da Lagoa do Casamento e dos Butiazais de Tapes, Planície Costeira do Rio Grande do Sul. Brasília, Ministério do Meio Ambiente MMA/SBF.

Podgaiski LR, Ott R, Rodrigues ENL, Buckup EH, Marques MAL (2007) Araneofauna (Arachnida; Araneae) do Parque Estadual do Turvo, Rio Grande do Sul, Brazil. Biota Neotropica 7: http://www.biotaneotropica.org.br/v7n2/pt/abstract?inventory+bn01107022007

PlatnICK NI (1999) Dimensions of biodiversity: targeting megadiverse groups, p. 33-52. In: Cracraft J, Grifo FT (Eds.). The living planet in crisis: Biodiversity science and policy. New York, Columbia University Press.

Raizer J, JaPyassú HF, IndicatTi RP, BRescovit AD (2005) Comunidade de aranhas (Arachnida, Araneae) do pantanal norte 
(Mato Grosso, Brazil) e sua similaridade com a araneofauna amazônica. Biota Neotropica 5: http://www.biotaneotropica. org.br/v5n1a/pt/abstract?inventory+ BN009051a2005

RINALDI IM, TRINCA LA (2008) Spider assemblages in widely-separated patches of Cerrado in São Paulo State, Brazil. Acta Biologica Paranaense 37: 165-180.

Rodrigues ENL (2005) Fauna araneológica (Arachnida; Araneae) arborícola de duas áreas em uma mata de restinga no sul do Brazil. Acta Biologica Leopoldensia 27: 73-92.

Rodrigues ENL, Marques MAL (2010) Sobre o gênero Phoroncidia: nova espécie, ecologia e descrição do macho de $P$. reimoseri com novas ocorrências para o sul do Brasil (Araneae, Theridiidae). Iheringia, Série Zoologia, 100: 247-253. doi: 10.1590/ S0073-47212010000300010

Rodrigues ENL, Otт R (2010) A new species of Psilocymcium with the descriptions of the male and new records of $P$. lineatum at South Brazil (Araneae: Linyphiidae). Zoologia 27: 445-450. doi: 10.1590/S1984-46702010000300018

Rodrigues ENL, MENDONÇA JR MS (2011) Araneid orb-weavers (Araneae, Araneidae) associated with riparian forests in southern Brazil: a new species, complementary descriptions and new records. Zootaxa 2759: 60-68.

Rodrigues ENL, MENDONÇA JR MS (2012) Spider guilds in the treeshrub strata of riparian forests in southern Brazil. Journal of Arachnology 40: 39-47.

Rodrigues ENL, BRescovit AD (2015) On the spider genus Thymoites in the Neotropical Region (Araneae, Theridiidae): nine new species, complementary descriptions and new records. Zootaxa 3972: 181-207. doi: 10.11646/zootaxa.3972.2.3

Rodrigues ENL, MENdonÇA JR MS, Costa-Schmidt LE (2014) Spider diversity responds strongly to edge effects but weakly to vegetation structure in riparian forests of Southern Brazil. Arthropod-Plant Interactions 8: 123-133. doi: 10.1007/ s11829-014-9294-3

Romero GQ, Vasconcelos-Neto J (2005) Spatial distribution and microhabitat preference of Psecas chapoda (Peckham \& Peckham) (Araneae, Salticidae). Journal of Arachnology 33: 124-134.

SAMu F, Sunderland KD, Szinetár C (1999) Scale-dependent dispersal and distribution patterns of spiders in agricultural systems: a review. Journal of Arachnology 27: 325-32.
SILVA D (1996) Species composition and community structure of Peruvian rainforest spiders: a case study from a seasonally inundated forest along the Samiria river. Revue Suisse de Zoologie, Hors Serie: 597-610.

Silva D, Coddington JA (1996) Spiders of Pakitza (Madre de Dios) Peru: species richness and notes on community structure, $p$. 241-299. In: WiLSON DE, SANDOVAL A (Eds.). The biodiversity of Pakitza and its environs. Washington, DC, Smithsonian Institution.

Silva ElC, Araújo AM (2005) Distribuição e diversidade das species de aranhas (Araneae) coletadas na região de Taínhas e Terra de Areia, Rio Grande do Sul, Brasil. Revista Brasileira de Zoociências 7: 285-296.

Sørensen LL, Coddington JA, ScharfF N (2002) Inventorying and estimating subcanopy spider diversity using semiquantitative sampling methods in an Afromontane Forest. Environmental Entomology 31: 319-330.

Tabarelli M, Pinto LP, Silva JMC, Hirota MM, Bedê LC (2005) Desafio e oportunidades para a conservação da biodiversidade na Mata Atlântica Brasileira, p. 132-138. In: Megadiversidade. Belo Horizonte, Conservação Internacional, vol. 1.

Uetz GW (1991) Habitat structure and spider foraging, p. 325348. In: Bell SS, McCoy ED, MushinsKy HR (Eds.). Habitat structure. The physical arrangement of objects in space. London, Chapman and Hall.

Wu YH, CHENG X (2012) Spider community structures in different types of hedgerows in the purple soil hilly areas of Sichuan Basin. Journal of Ecology and Rural Environment 28: 661-668.

Submitted: 15 July 2015

Received in revised form: 22 December 2015

Accepted: 16 March 2016

Editorial responsibility: Antonio D. Brescovit

Author Contributions. ENLR and MSMJ designed sampling, ENLR and PESR conducted sampling, ENLR, PESR and MSM] analysed the data and wrote the paper.

Competing Interests. The authors have declared that no competing interests exist. 
Appendix 1. Species/morphospecies list for spiders sampled in riparian forests and respective microhabitats (edges and forest interior) in southern Brazil. (GE) Grassland edge, (RE) river edge, (FI) forest interior.

\begin{tabular}{|c|c|c|c|c|c|c|c|c|c|c|c|c|c|c|}
\hline \multirow{3}{*}{ Taxa } & \multicolumn{12}{|c|}{ Riparian forests/microhabitats } & \multirow{3}{*}{ Total } & \multirow{3}{*}{$\%$} \\
\hline & \multicolumn{3}{|c|}{ Piratini } & \multicolumn{3}{|c|}{ Camaquã } & \multicolumn{3}{|c|}{ Sinos } & \multicolumn{3}{|c|}{ Maquiné } & & \\
\hline & $\mathrm{RE}$ & $\mathrm{FI}$ & GE & $\mathrm{RE}$ & $\mathrm{FI}$ & GE & $\mathrm{RE}$ & $\mathrm{FI}$ & GE & $\mathrm{RE}$ & $\mathrm{FI}$ & GE & & \\
\hline \multicolumn{15}{|l|}{ Amaurobiidae } \\
\hline Amaurobiidae undet. & & 1 & & 2 & & & 1 & & & & & & 4 & 0.05 \\
\hline \multicolumn{15}{|l|}{ Anyphaenidae } \\
\hline Anyphaenoides clavipes (Mello-Leitão, 1922) & & 2 & & & & & 1 & & 3 & 2 & & & 8 & 0.09 \\
\hline Arachosia praesignis (Keyserling, 1891) & 7 & & 1 & & & & & & & & & & 8 & 0.09 \\
\hline Arachosia sp. & 1 & & & & & & & & & & & & 1 & 0.01 \\
\hline Aysha borgmeyeri (Mello-Leitão, 1926) & & 3 & 1 & & 4 & & & & & & & & 8 & 0.09 \\
\hline Aysha chicama Brescovit,1992 & & & & 3 & & & & & & & & & 3 & 0.03 \\
\hline Aysha ericae Brescovit, 1992 & & & & & 2 & & & 2 & & 1 & & & 5 & 0.06 \\
\hline Aysha helvola (Keyserling, 1891) & & & & & & & & & & & 1 & & 1 & 0.01 \\
\hline Aysha montenegro Brescovit,1992 & & 1 & & & 3 & 2 & 1 & 6 & & & & & 13 & 0.15 \\
\hline Aysha rubromaculata (Keyserling, 1891) & & & 1 & & & & & & 1 & & & & 2 & 0.02 \\
\hline Aysha triunfo Brescovit, 1992 & 1 & & & & & & 2 & & 2 & 1 & & 2 & 8 & 0.09 \\
\hline Aysha sp. 1 & 3 & & & & & & & & & & & & 3 & 0.03 \\
\hline Aysha sp. 2 & & 2 & 5 & & & & & & & & & & 7 & 0.08 \\
\hline Aysha sp. 3 & 1 & & 1 & & & & & & & & & & 2 & 0.02 \\
\hline Aysha sp. 4 & 1 & 12 & & & 3 & 1 & & 2 & & & & & 19 & 0.21 \\
\hline Aysha sp. 5 & 1 & & 3 & & & & & & 1 & & & & 5 & 0.06 \\
\hline Aysha sp. 6 & & & & & & & 1 & & & & & & 1 & 0.01 \\
\hline Aysha sp. 7 & & 1 & & & 1 & & & 2 & & & & & 4 & 0.05 \\
\hline Aysha sp. 8 & & & & & & & & & & 1 & & & 1 & 0.01 \\
\hline Jessica osoriana (Mello-Leitão, 1922) & & & & & & & & & 1 & & & & 1 & 0.01 \\
\hline Jessica sp. & 1 & & & & & 1 & & & & & & & 2 & 0.02 \\
\hline Patrera longipes (Keyserling, 1891) & & 7 & & 1 & 5 & 2 & 1 & & & & 4 & & 20 & 0.23 \\
\hline Patrera procera (Keyserling, 1891) & & 1 & & & & & 1 & 2 & & 1 & & & 5 & 0.06 \\
\hline Sanogasta maculatipes (Keyserling, 1878) & 1 & & & & & & & & & & & & 1 & 0.01 \\
\hline Sanogasta maculosa (Nicolet, 1849) & & & & & & 1 & & & & & & & 1 & 0.01 \\
\hline Sanogasta sp. 1 & & & & & & 1 & & & & & & & 1 & 0.01 \\
\hline Sanogasta sp. 2 & & & & & & & & & & & & 1 & 1 & 0.01 \\
\hline Sanogasta sp. 3 & 1 & 1 & & & & & & & & & 1 & & 3 & 0.03 \\
\hline Tasata variolosa Mello-Leitão, 1943 & 3 & 3 & & 1 & 5 & 1 & & & & & & & 13 & 0.15 \\
\hline Tasata sp. 1 & & 1 & & & & 1 & & & 1 & & & 1 & 4 & 0.05 \\
\hline Tasata sp. 2 & 1 & & 1 & & & & & & & & & & 2 & 0.02 \\
\hline Tasata sp. 3 & & & & & & & & & & & 1 & & 1 & 0.01 \\
\hline Wulfila albus (Mello-Leitão, 1945) & & 4 & & & 1 & 1 & 2 & 2 & 1 & 5 & & 1 & 17 & 0.19 \\
\hline Wulfilopsis sp. & & & & 4 & 6 & 1 & & & & & & & 11 & 0.12 \\
\hline Wulfilopsis tripunctata (Mello-Leitão, 1947) & & & & & & & & & & 5 & 12 & & 17 & 0.19 \\
\hline Xiruana gracilipes (Keyserling, 1891) & 1 & & 3 & & & & & & & & & & 4 & 0.05 \\
\hline Xiruana sp. & & 1 & & 1 & & & & & 1 & & & & 3 & 0.03 \\
\hline \multicolumn{15}{|l|}{ Araneidae } \\
\hline Acasesia graciosa Lise \& Braul, 1995 & & & & & 1 & & & & & & & 2 & 3 & 0.03 \\
\hline Alpaida alticeps (Keyserling, 1880) & & & & & & & & & & & 2 & 2 & 4 & 0.05 \\
\hline Alpaida citrina (Keyserling, 1892) & & & & & & & & & & & & 10 & 10 & 0.11 \\
\hline Alpaida erica Levi, 1988 & & & 1 & & & & & & & & & & 1 & 0.01 \\
\hline Alpaida grayi (Blackwall, 1863) & & & & & & & & & & & & 5 & 5 & 0.06 \\
\hline Alpaida lomba Levi, 1988 & & & 1 & & & & & & & & & & 1 & 0.01 \\
\hline Alpaida nonoai Levi, 1988 & & & & & & 2 & & & & & & & 2 & 0.02 \\
\hline Alpaida octolobata Levi, 1988 & & 4 & & & 12 & & & & & & & & 16 & 0.18 \\
\hline Alpaida pedro Levi, 1988 & & & & & 1 & & & & & & 2 & & 3 & 0.03 \\
\hline Alpaida truncata (Keyserling, 1865) & & & & & & & & 1 & & & & & 1 & 0.01 \\
\hline Araneus omnicolor (Keyserling, 1893) & 1 & 2 & & 1 & 1 & & & 2 & & 1 & 5 & & 13 & 0.15 \\
\hline Araneus unanimus (Keyserling, 1880) & & & 4 & 2 & 1 & 1 & & & & & & & 8 & 0.09 \\
\hline
\end{tabular}


Appendix 1. Continued.

\begin{tabular}{|c|c|c|c|c|c|c|c|c|c|c|c|c|c|c|}
\hline \multirow{3}{*}{ Taxa } & \multicolumn{12}{|c|}{ Riparian forests/microhabitats } & \multirow{3}{*}{ Total } & \multirow{3}{*}{$\%$} \\
\hline & \multicolumn{3}{|c|}{ Piratini } & \multicolumn{3}{|c|}{ Camaquã } & \multicolumn{3}{|c|}{ Sinos } & \multicolumn{3}{|c|}{ Maquiné } & & \\
\hline & RE & $\mathrm{FI}$ & GE & RE & $\mathrm{FI}$ & GE & RE & $\mathrm{FI}$ & GE & RE & $\mathrm{FI}$ & GE & & \\
\hline Araneus uniformis (Keyserling, 1880) & & & 2 & & & & & & & & & & 2 & 0.02 \\
\hline Araneus venatrix (C.L. Koch, 1839) & & 1 & & & & & & & & 1 & 1 & 1 & 4 & 0.05 \\
\hline Araneus vincibilis (Keyserling, 1893) & & 3 & & & & & & 2 & 1 & & & & 6 & 0.07 \\
\hline Bertrana rufostriata Simon, 1893 & & & 1 & & & & & & 5 & & & 1 & 7 & 0.08 \\
\hline Cyclosa camargoi Levi, 1999 & & & & & & 1 & & & & & & & 1 & 0.01 \\
\hline Cyclosa diversa (O.P.-Cambridge, 1894) & & & & & & & 1 & & & & & & 1 & 0.01 \\
\hline Cyclosa fililineata Hingston, 1932 & & 2 & & & 1 & & & 7 & & & & & 10 & 0.11 \\
\hline Cyclosa inca Levi, 1999 & & & & 2 & & & & & & & & & 2 & 0.02 \\
\hline Cyclosa machadinho Levi, 1999 & & & 1 & & 1 & & 1 & 5 & 1 & 1 & 6 & & 16 & 0.18 \\
\hline Cyclosa morretes Levi, 1999 & & & 1 & & 1 & & & & & & & & 2 & 0.02 \\
\hline Eustala albiventer (Keyserling, 1884) & 2 & & & & & 1 & & & & & & & 3 & 0.03 \\
\hline Eustala crista Poeta, Marques \& Buckup, 2010 & & & & & 1 & & & & & & & & 1 & 0.01 \\
\hline Eustala levii Poeta, Marques \& Buckup, 2010 & & & 4 & & & & & & & & & & 4 & 0.05 \\
\hline Eustala palmares Poeta, Marques \& Buckup,2010 & 3 & & 4 & & & & & & & & & 1 & 8 & 0.09 \\
\hline Eustala photographica Mello-Leitão, 1944 & 10 & & 1 & 3 & & & & & & & & & 14 & 0.16 \\
\hline Eustala saga (Keyserling, 1893) & & & & & & & & & & & & 1 & 1 & 0.01 \\
\hline Eustala taquara (Keyserling, 1892) & & & 5 & 4 & & 12 & 8 & & 9 & & & 3 & 41 & 0.46 \\
\hline Eustala sp. 1 & & & & & & & & & & & & 1 & 1 & 0.01 \\
\hline Eustala sp. 2 & & & & 1 & & & & & & & & & 1 & 0.01 \\
\hline Eustala sp. 3 & & & & & & & & & 1 & & & & 1 & 0.01 \\
\hline Gasteracantha cancriformis (Linnaeus, 1767) & 2 & 1 & 2 & & & & 1 & & & & & 3 & 9 & 0.1 \\
\hline Hypognatha viamao Levi, 1996 & & 1 & 1 & & & & & & & & 1 & 1 & 4 & 0.05 \\
\hline Larinia montecarlo (Levi, 1998) & & & & & & 1 & 1 & & & & & & 2 & 0.02 \\
\hline Mangora fundo Levi, 2007 & 1 & & 3 & & & & & & & & & 1 & 5 & 0.06 \\
\hline Mangora lactea Mello-Leitão, 1944 & & 1 & 2 & & & & & & & & & & 3 & 0.03 \\
\hline Mangora melanocephala (Taczanowski, 1878) & & & & & & & 1 & & 3 & & & & 4 & 0.05 \\
\hline Mangora missa Levi, 2007 & & & & & & & & & & & 1 & & 1 & 0.01 \\
\hline Mangora piratini Rodrigues \& Mendonça, 2011 & & 1 & & & & & & & & & & & 1 & 0.01 \\
\hline Mangora strenua (Keyserling, 1893) & 11 & 68 & 8 & 8 & 21 & 1 & 1 & 9 & & 3 & 3 & 1 & 134 & 1.51 \\
\hline Mecynogea bigibba Simon, 1903 & & & & & & 1 & 1 & & 1 & & & & 3 & 0.03 \\
\hline Metazygia floresta Levi, 1995 & & & & & & & & & 1 & & & & 1 & 0.01 \\
\hline Metazygia genialis (Keyserling, 1892) & & & & & & 1 & & & & & & & 1 & 0.01 \\
\hline Metazygia lagiana Levi, 1995 & & & & & & & 1 & & & & & & 1 & 0.01 \\
\hline Metepeira compsa (Chamberlin, 1916) & & & & & & & & & 1 & & & & 1 & 0.01 \\
\hline Metepeira glomerabilis (Keyserling, 1892) & & & & & & & & & 1 & & & & 1 & 0.01 \\
\hline Micrathena furva (Keyserling, 1892) & & 1 & & & & & & & & & & & 1 & 0.01 \\
\hline Micrathena guanabara Levi, 1985 & & 2 & & & 2 & & & 6 & & 1 & 2 & & 13 & 0.15 \\
\hline Micrathena jundiai Levi, 1985 & & & & & & & & & & & & 2 & 2 & 0.02 \\
\hline Micrathena lata Chickering, 1960 & & & 1 & & & & & & & & & & 1 & 0.01 \\
\hline Micrathena nigrichelis Chickering, 1960 & & & & & & & & & & & 1 & & 1 & 0.01 \\
\hline Micrathena spitzi Mello-Leitão, 1932 & 3 & 24 & 3 & 6 & 3 & 1 & & & & 1 & & & 41 & 0.46 \\
\hline Ocrepeira fiebrigi (Dahl, 1906) & & & & & & & & & 1 & & & & 1 & 0.01 \\
\hline Ocrepeira galianoae Levi, 1993 & 2 & 2 & 4 & & & & & & & & & & 8 & 0.09 \\
\hline Ocrepeira gnomo (Mello-Leitão, 1943) & 1 & & 2 & 1 & 1 & & & & & & 1 & & 6 & 0.07 \\
\hline Ocrepeira malleri Levi, 1993 & & & & 1 & & & & & & & & & 1 & 0.01 \\
\hline Parawixia audax (Blackwall, 1863) & & & & & 1 & & 1 & & & 3 & & 2 & 7 & 0.08 \\
\hline Parawixia velutina (Taczanowski, 1878) & & & & & & & & 1 & & & & & 1 & 0.01 \\
\hline Scoloderus cordatus (Taczanowski, 1879) & 1 & 4 & 14 & 8 & 4 & 16 & 1 & 14 & 1 & 4 & 2 & & 69 & 0.78 \\
\hline Testudinaria lemniscata (Simon, 1893) & & & & & & & & & & & 10 & & 10 & 0.11 \\
\hline Testudinaria quadripunctata Taczanowski, 1879 & & & & & & & & & & & & 1 & 1 & 0.01 \\
\hline Verrucosa meridionalis (Keyserling, 1892) & & & & & & & & & & & 3 & & 3 & 0.03 \\
\hline Verrucosa undecimvariolata (O.P.-Cambridge,1889) & & & 3 & & & & & & & & & & 3 & 0.03 \\
\hline Wagneriana taim Levi, 1991 & & & & 2 & & & & & & & & & 2 & 0.02 \\
\hline
\end{tabular}


Appendix 1. Continued.

\begin{tabular}{|c|c|c|c|c|c|c|c|c|c|c|c|c|c|c|}
\hline \multirow{3}{*}{ Taxa } & \multicolumn{12}{|c|}{ Riparian forests/microhabitats } & \multirow{3}{*}{ Total } & \multirow{3}{*}{$\%$} \\
\hline & \multicolumn{3}{|c|}{ Piratini } & \multicolumn{3}{|c|}{ Camaquã } & \multicolumn{3}{|c|}{ Sinos } & \multicolumn{3}{|c|}{ Maquiné } & & \\
\hline & RE & $\mathrm{FI}$ & GE & $\mathrm{RE}$ & $\mathrm{FI}$ & GE & $\mathrm{RE}$ & $\mathrm{FI}$ & GE & RE & $\mathrm{FI}$ & GE & & \\
\hline \multicolumn{15}{|l|}{ Clubionidae } \\
\hline Elaver brevipes (Keyserling, 1891) & & & & & & & & & & 1 & & & 1 & 0.01 \\
\hline \multicolumn{15}{|l|}{ Corinnidae } \\
\hline Castianeira sp. & 1 & & 1 & & & & & & & & & & 2 & 0.02 \\
\hline \multicolumn{15}{|l|}{ Deinopidae } \\
\hline Deinopis amica Schiapelli \& Gerschman, 1957 & & 1 & & & 2 & & & 2 & & 1 & & 1 & 7 & 0.08 \\
\hline Deinopis sp. 1 & & & & & & & 1 & & & & & 1 & 2 & 0.02 \\
\hline Deinopis sp. 2 & & & & & 1 & & & & & & & & 1 & 0.01 \\
\hline \multicolumn{15}{|l|}{ Dictynidae } \\
\hline Dictynidae undet. & & & 1 & & & & & & & & & & 1 & 0.01 \\
\hline \multicolumn{15}{|l|}{ Eutichuridae } \\
\hline Cheiracanthium inclusum (Hentz, 1847) & 6 & & 1 & & & 1 & & & 4 & & & 2 & 14 & 0.16 \\
\hline Eutichurus ravidus Simon, 1896 & & & & & & & & & & & & 1 & 1 & 0.01 \\
\hline \multicolumn{15}{|l|}{ Gnaphosidae } \\
\hline Zimiromus montenegro Buckup \& Brescovit, 1993 & & & & & & & & & & & 1 & & 1 & 0.01 \\
\hline Hahniidae & & & & & & & & & & & & & & \\
\hline Hahnia sp. & & & & & & & & & & 32 & 16 & 8 & 56 & 0.63 \\
\hline Linyphiidae & & & & & & & & & & & & & & \\
\hline Anodoration claviferum Millidge, 1991 & & & 12 & & 1 & 4 & 9 & 13 & 2 & 4 & 1 & 10 & 56 & 0.63 \\
\hline Asemostera latithorax (Keyserling, 1886) & & & 1 & & & & & & & & & & 1 & 0.01 \\
\hline Asemostera tacuapi Rodrigues, 2007 & & & 1 & & & & 3 & & 1 & 1 & 3 & & 9 & 0.1 \\
\hline Dubiaranea sp. & & & & & & & & & & 2 & 1 & & 3 & 0.03 \\
\hline Erigone sp. & 2 & & 2 & 1 & & 6 & 1 & 2 & 6 & & 1 & & 21 & 0.24 \\
\hline Erigoninae undet. & 1 & & & & & & & & & & & & 1 & 0.01 \\
\hline Laminacauda montevidensis (Keyserling, 1878) & & 1 & 3 & & & & & & & & & & 4 & 0.05 \\
\hline Laminacauda sp. & & & & & & & & & 1 & & & & 1 & 0.01 \\
\hline Lepthyphantes sp. 1 & & & 1 & 1 & & & & & & 1 & & & 3 & 0.03 \\
\hline Lepthyphantes sp. 2 & & & & 1 & & & & & 4 & & & & 5 & 0.06 \\
\hline Lepthyphantes sp. 3 & & & 1 & & & & & & & & & & 1 & 0.01 \\
\hline Linyphiinae undet. & & & & & & & & & & 1 & & & 1 & 0.01 \\
\hline Lygarina sp. 1 & 1 & & 1 & & & & & & & & & & 2 & 0.02 \\
\hline Lygarina sp. 2 & & & & & & & & & & 1 & 5 & & 6 & 0.07 \\
\hline Lygarina sylvicola Millidge, 1991 & 11 & & 6 & & & 5 & & & & & & & 22 & 0.25 \\
\hline Meioneta sp. 1 & 3 & 1 & & 3 & 4 & 2 & 2 & & 1 & & & & 16 & 0.18 \\
\hline Meioneta sp. 2 & & 2 & 1 & 1 & & 1 & & & & & & & 5 & 0.06 \\
\hline Meioneta sp. 3 & & & & & & & 1 & & & & & & 1 & 0.01 \\
\hline Meioneta sp. 4 & & & & & & & & & 3 & & & & 3 & 0.03 \\
\hline Mermessus sp. & 1 & & & & & & & & & & & 1 & 2 & 0.02 \\
\hline Neomaso sp. & 2 & 1 & & & & & & & & & & & 3 & 0.03 \\
\hline Notiohyphantes excelsus (Keyserling, 1886) & 1 & & & & & & & & 2 & & & & 3 & 0.03 \\
\hline Psilocymbium lineatum (Millidge, 1991) & & & 1 & & & 1 & & & & & & & 2 & 0.02 \\
\hline Scolecura cambara Rodrigues, 2005 & & & & & 1 & & & & & & & & 1 & 0.01 \\
\hline Scolecura parilis Millidge, 1991 & 3 & 2 & & & & & & & & & & & 5 & 0.06 \\
\hline Smermisia sp. & & & & & & 2 & & & & & & & 2 & 0.02 \\
\hline Sphecozone diversicolor (Keyserling, 1886) & & & & & & 1 & & & & 1 & & & 2 & 0.02 \\
\hline Sphecozone ignigena (Keyserling, 1891) & 9 & 2 & & 8 & 2 & 1 & & & 1 & & & 2 & 25 & 0.28 \\
\hline Sphecozone personata (Simon, 1894) & & & & & & & & 1 & 1 & 293 & 598 & 329 & 1222 & 13.8 \\
\hline Sphecozone rostrata Millidge, 1991 & & & & & 2 & & & 15 & 22 & & 55 & 6 & 100 & 1.13 \\
\hline Sphecozone sp. 1 & & & 1 & & & & & & & & & & 1 & 0.01 \\
\hline Sphecozone sp. 2 & & & & & & & & & & & & 1 & 1 & 0.01 \\
\hline Sphecozone sp. 3 & & & & & & & & & & 1 & & & 1 & 0.01 \\
\hline Sphecozone sp. 4 & 1 & & & & & & & & & & & & 1 & 0.01 \\
\hline Sphecozone sp. 5 & 1 & & & & & & & & & & & & 1 & 0.01 \\
\hline
\end{tabular}


Appendix 1. Continued.

\begin{tabular}{|c|c|c|c|c|c|c|c|c|c|c|c|c|c|c|}
\hline \multirow{3}{*}{ Taxa } & \multicolumn{12}{|c|}{ Riparian forests/microhabitats } & \multirow{3}{*}{ Total } & \multirow{3}{*}{$\%$} \\
\hline & \multicolumn{3}{|c|}{ Piratini } & \multicolumn{3}{|c|}{ Camaquã } & \multicolumn{3}{|c|}{ Sinos } & \multicolumn{3}{|c|}{ Maquiné } & & \\
\hline & RE & $\mathrm{FI}$ & GE & $\mathrm{RE}$ & $\mathrm{FI}$ & $\mathrm{GE}$ & RE & $\mathrm{FI}$ & GE & $\mathrm{RE}$ & $\mathrm{FI}$ & GE & & \\
\hline Sphecozone sp. 6 & & & 4 & & & & & & 1 & & & & 5 & 0.06 \\
\hline Triplogyna ignitula (Keyserling, 1886) & 2 & & & 2 & & 1 & & & & & & & 5 & 0.06 \\
\hline Tutaibo aff. debilipes & & & & & & & 6 & & & & & & 6 & 0.07 \\
\hline Tutaibo rusticellus (Keyserling, 1891) & & & & & & 5 & 2 & & 1 & & & & 8 & 0.09 \\
\hline Tutaibo velox (Keyserling, 1886) & & & & & & 1 & & & & & & & 1 & 0.01 \\
\hline Tutaibo sp. 1 & 4 & & & 4 & 5 & 2 & 1 & & 1 & & & & 17 & 0.19 \\
\hline Tutaibo sp. 2 & 2 & & & & 1 & 1 & 1 & & & & & & 5 & 0.06 \\
\hline Tutaibo sp. 3 & 32 & & 1 & 10 & 2 & 15 & & & & & & & 60 & 0.68 \\
\hline Tutaibo sp. 4 & & & & & & & & & 4 & & & & 4 & 0.05 \\
\hline Tutaibo sp. 5 & & & & & 1 & & 1 & & & & & & 2 & 0.02 \\
\hline \multicolumn{15}{|l|}{ Mimetidae } \\
\hline Gelanor altithorax Keyserling, 1893 & & & & & 3 & 2 & & 2 & & & & & 7 & 0.08 \\
\hline Gelanor zonatus (C. L. Koch, 1845) & 1 & 9 & 2 & 1 & 4 & 2 & 1 & 3 & 1 & & & & 24 & 0.27 \\
\hline Mimetinae undet. 1 & & 3 & & 2 & 49 & 3 & & 8 & & & & & 65 & 0.73 \\
\hline Mimetinae undet. 2 & & 12 & & & 6 & 1 & & 5 & & 1 & 3 & & 28 & 0.32 \\
\hline Mimetinae undet. 3 & & & & & & & & & & & 1 & 1 & 2 & 0.02 \\
\hline Mimetus hieroglyphicus (Mello-Leitão, 1929) & 2 & & 1 & & & & & & & & & & 3 & 0.03 \\
\hline \multicolumn{15}{|l|}{ Mysmenidae } \\
\hline Trogloneta cantareira Brescovit \& Lopardo, 2008 & & 1 & & 1 & 1 & 2 & & & & & & & 5 & 0.06 \\
\hline \multicolumn{15}{|l|}{ Nephiliidae } \\
\hline Nephila clavipes (Linnaeus, 1767) & 3 & 3 & & 4 & 3 & 4 & 6 & 16 & 2 & & 1 & 2 & 44 & 0.50 \\
\hline \multicolumn{15}{|l|}{ Oonopidae } \\
\hline Gamasomorpha sp. 1 & & 2 & & & & 1 & & & & & & & 3 & 0.03 \\
\hline Gamasomorpha sp. 2 & & & & & & 1 & & & & & 1 & 2 & 4 & 0.05 \\
\hline Oonops sp. & & & & & & & & 1 & & & 2 & & 3 & 0.03 \\
\hline Orchestina sp. 1 & 13 & 2 & 3 & 7 & 13 & & 3 & & 2 & 5 & 13 & 1 & 62 & 0.70 \\
\hline Orchestina sp. 2 & & & & & & & & & & 1 & & 1 & 2 & 0.02 \\
\hline Orchestina sp. 3 & & & & & 1 & & & & & & & & 1 & 0.01 \\
\hline \multicolumn{15}{|l|}{ Oxyopidae } \\
\hline Hamataliwa sp. & & & & & & & & & 2 & & & 1 & 3 & 0.03 \\
\hline Oxyopes sp. & & & & & & 1 & 1 & 5 & 1 & & & & 8 & 0.09 \\
\hline \multicolumn{15}{|l|}{ Philodromidae } \\
\hline Berlandiella magna Mello-Leitão, 1929 & & & & & & & 2 & 3 & 6 & & 8 & 7 & 26 & 0.29 \\
\hline Berlandiella sp. 1 & & & & & & & & & & 1 & & & 1 & 0.01 \\
\hline Berlandiella sp. 2 & & & & & & 1 & & & & & & & 1 & 0.01 \\
\hline Philodromidae undet. & & & & & & & & & & 1 & & 1 & 2 & 0.02 \\
\hline Pholcidae & & & & & & & & & & & & & & \\
\hline Mesabolivar aff. cyaneomaculatus & & 1 & & 1 & 2 & 2 & & & & & & & 6 & 0.07 \\
\hline Mesabolivar luteus (Keyserling, 1891) & & & & & & & 2 & 8 & 1 & & & & 11 & 0.12 \\
\hline Metagonia argentinensis Mello-Leitão, 1945 & & & & & & & 4 & 1 & 4 & & & & 9 & 0.10 \\
\hline Metagonia sp. & & & & 1 & 47 & 8 & & & & 17 & 64 & 3 & 140 & 1.58 \\
\hline Tupigea paula Huber, 2000 & & & & & 4 & & & & & & & & 4 & 0.05 \\
\hline Tupigea sp. & & & & & 1 & & 1 & & & & & & 2 & 0.02 \\
\hline Salticidae & & & & & & & & & & & & & & \\
\hline Acragas nigromaculatus (Mello-Leitão, 1922) & & & & & & & & & 1 & & & & 1 & 0.01 \\
\hline Ashtabula sp. 1 & & 5 & & 4 & 3 & & & & & & & & 12 & 0.14 \\
\hline Ashtabula sp. 2 & & & & & & 1 & & & & & & & 1 & 0.01 \\
\hline Atelurius segmentatus Simon, 1901 & & & & 2 & & & & & & & & & 2 & 0.02 \\
\hline Beata aff. maccuni & & & & & & & 1 & & & & & & 1 & 0.01 \\
\hline Beata sp. & & & & & & & & & 1 & & & & 1 & 0.01 \\
\hline Chira sp. & & & & & & & & & & & 1 & & 1 & 0.01 \\
\hline Chira thysbe Simon, 1902 & 7 & & 2 & 1 & & 1 & 7 & & 3 & & & 2 & 23 & 0.26 \\
\hline Chirothecia semiornata Simon, 1901 & & & 1 & 2 & & 6 & & & & 1 & & 2 & 12 & 0.14 \\
\hline
\end{tabular}


Appendix 1. Continued.

\begin{tabular}{|c|c|c|c|c|c|c|c|c|c|c|c|c|c|c|}
\hline \multirow{3}{*}{ Taxa } & \multicolumn{12}{|c|}{ Riparian forests/microhabitats } & \multirow{3}{*}{ Total } & \multirow{3}{*}{$\%$} \\
\hline & \multicolumn{3}{|c|}{ Piratini } & \multicolumn{3}{|c|}{ Camaquã } & \multicolumn{3}{|c|}{ Sinos } & \multicolumn{3}{|c|}{ Maquiné } & & \\
\hline & RE & $\mathrm{FI}$ & GE & RE & $\mathrm{FI}$ & GE & RE & $\mathrm{FI}$ & GE & RE & $\mathrm{FI}$ & GE & & \\
\hline Chirothecia sp. 1 & & & & 1 & 1 & 6 & & & & & & & 8 & 0.09 \\
\hline Chirothecia sp. 2 & & & & & & & & & 1 & & & & 1 & 0.01 \\
\hline Coryphasia albibarbis Simon, 1902 & & & & 1 & 1 & & 1 & 3 & 2 & & & 1 & 9 & 0.10 \\
\hline Coryphasia sp. 1 & & & & & & & & & & & 1 & & 1 & 0.01 \\
\hline Coryphasia sp. 2 & & & & & 7 & 3 & & & & & & & 10 & 0.11 \\
\hline Corythalia sp. 1 & 2 & & & 2 & & & & & & & & & 4 & 0.05 \\
\hline Corythalia sp. 2 & & & & & & & 1 & & & & & & 1 & 0.01 \\
\hline Cotinusa aff. deserta & 5 & 8 & 3 & 9 & 17 & 5 & & & & 26 & 25 & 2 & 100 & 1.13 \\
\hline Cotinusa trifasciata (Mello-Leitão, 1943) & 9 & 22 & 27 & 14 & 29 & 6 & 14 & 19 & 2 & 36 & 26 & & 204 & 2.30 \\
\hline Cotinusa sp. 1 & & & & & & & & & 1 & 1 & & & 2 & 0.02 \\
\hline Cotinusa sp. 2 & & & & & & 3 & & & & & & & 3 & 0.03 \\
\hline Cotinusa sp. 3 & & & 2 & & 1 & 2 & & & & 6 & & 1 & 12 & 0.14 \\
\hline Cotinusa sp. 4 & 1 & & & & 1 & 2 & 1 & & & 1 & & & 6 & 0.07 \\
\hline Cotinusa sp. 5 & & & & & & & & & 1 & & & & 1 & 0.01 \\
\hline Cylistella cuprea (Simon, 1864) & & & & 7 & 27 & 1 & & & & 4 & 11 & & 50 & 0.56 \\
\hline Cylistella sp. 1 & & 1 & & & & & & & & & & & 1 & 0.01 \\
\hline Cylistella sp. 2 & & & & & & & & & & 1 & & 1 & 2 & 0.02 \\
\hline Cylistella sp. 3 & & & & & & & & 1 & & 3 & 7 & 1 & 12 & 0.14 \\
\hline Dendryphantes sp. & 1 & & & & & & & & & & & & 1 & 0.01 \\
\hline Euophrys saitiformis Simon, 1901 & & & & & 1 & & & & & & & & 1 & 0.01 \\
\hline Gastromicans albopilosa (Simon, 1903) & 1 & & & & & & & & 1 & & & & 2 & 0.02 \\
\hline Hasarius lisei Vianna \& Soares, 1982 & & & & & & 1 & & & & & & & 1 & 0.01 \\
\hline Hasarius sp. & 9 & & 5 & 9 & & 4 & 6 & 1 & 13 & & & & 47 & 0.53 \\
\hline Lyssomanes leucomelas Mello-Leitão, 1917 & & & & & & & & & & 1 & & & 1 & 0.01 \\
\hline Lyssomanes nigrofimbriatus Mello-Leitão, 1940 & & & & 4 & 1 & 3 & 2 & & 3 & & & & 13 & 0.15 \\
\hline Lyssomanes pauper Mello-Leitão, 1945 & 15 & & 6 & & & & & & & & & & 21 & 0.24 \\
\hline Mopiopia labyrinthea (Mello-Leitão, 1947) & & & & & & & 21 & 10 & 4 & 8 & 13 & 2 & 58 & 0.66 \\
\hline Mopiopia sp. & & & & & & & & 1 & & 4 & 2 & & 7 & 0.08 \\
\hline Myrmarachne sp. & & & & & & & & & & & 1 & 2 & 3 & 0.03 \\
\hline Noegus australis (Mello-Leitão, 1941) & & & & & 8 & & 4 & 7 & & & 6 & & 25 & 0.28 \\
\hline Paradescanso aff. fallax & & & & & 1 & 1 & & & & & & & 2 & 0.02 \\
\hline Rudra sp. & 2 & & 1 & & & 1 & & & & & & & 4 & 0.05 \\
\hline Sarinda sp. & & & & & & & & & & 3 & & & 3 & 0.03 \\
\hline Sassacus sp. 1 & & & & & & & 1 & & 3 & & & 10 & 14 & 0.16 \\
\hline Sassacus sp. 2 & & & & & & & & & & & & 1 & 1 & 0.01 \\
\hline Synemosyna aurantiaca (Mello-Leitão, 1917) & 1 & & 1 & & & & & & & & & 1 & 3 & 0.03 \\
\hline Synemosyna lauretta Peckham \& Peckham, 1892 & & & & & & & & & & & & 2 & 2 & 0.02 \\
\hline Tacuna delecta Peckham \& Peckham, 1901 & & & & 4 & & 2 & 3 & & 1 & & & 13 & 23 & 0.26 \\
\hline Tariona bruneti Simon, 1903 & & & & & & & 1 & 1 & & 3 & 5 & & 10 & 0.11 \\
\hline Thiodina robusta Mello-Leitão, 1945 & & & & & & 1 & & & 1 & & & 1 & 3 & 0.03 \\
\hline Tulpius gauchus Vianna \& Soares, 1983 & 2 & 2 & & 1 & 1 & & & & & & & & 6 & 0.07 \\
\hline Unidentati undet. & & & & & & & 1 & & & & & 1 & 2 & 0.02 \\
\hline Vinnius sp. & & & & & & & & & 1 & & & & 1 & 0.01 \\
\hline Vinnius uncatus Simon, 1902 & & & & & & & & 2 & & & & 5 & 7 & 0.08 \\
\hline \multicolumn{15}{|l|}{ Scytodiidae } \\
\hline Scytodes maquine Rheims \& Brescovit, 2009 & & & & & & & & & & 2 & 7 & 3 & 12 & 0.14 \\
\hline \multicolumn{15}{|l|}{ Senoculiidae } \\
\hline Senoculus purpureus (Simon, 1880) & 2 & & 1 & & & & 2 & 1 & 1 & 1 & & & 8 & 0.09 \\
\hline Senoculus sp. & & & & & & & & & & & 1 & & 1 & 0.01 \\
\hline \multicolumn{15}{|l|}{ Sparassidae } \\
\hline Caayguara album (Mello-Leitão, 1918) & & & & 1 & 1 & & & & & & & & 2 & 0.02 \\
\hline Polybetes germaini Simon, 1896 & & & & & & & & & & & 1 & 1 & 2 & 0.02 \\
\hline Polybetes rubrosignatus Mello-Leitão, 1943 & & & & & & & 3 & 2 & 2 & & 1 & & 8 & 0.09 \\
\hline & & & & & & & & & & & & & & ontinue \\
\hline
\end{tabular}


Appendix 1. Continued.

\begin{tabular}{|c|c|c|c|c|c|c|c|c|c|c|c|c|c|c|}
\hline \multirow{3}{*}{ Taxa } & \multicolumn{12}{|c|}{ Riparian forests/microhabitats } & \multirow{3}{*}{ Total } & \multirow{3}{*}{$\%$} \\
\hline & \multicolumn{3}{|c|}{ Piratini } & \multicolumn{3}{|c|}{ Camaquã } & \multicolumn{3}{|c|}{ Sinos } & \multicolumn{3}{|c|}{ Maquiné } & & \\
\hline & RE & $\mathrm{FI}$ & GE & RE & $\mathrm{FI}$ & GE & RE & $\mathrm{FI}$ & GE & RE & $\mathrm{FI}$ & GE & & \\
\hline Polybetes sp. & & & & & & & & & & 1 & & & 1 & 0.01 \\
\hline \multicolumn{15}{|l|}{ Synotaxidae } \\
\hline Synotaxus longicaudatus (Keyserling, 1891) & & & & & & & & & & & 3 & 1 & 4 & 0.05 \\
\hline \multicolumn{15}{|l|}{ Trachelidae } \\
\hline Meriola cetiformis (Strand, 1908) & 1 & & & & & & & & & & & & 1 & 0.01 \\
\hline Trachelas sp. 1 & & & 1 & 1 & & & & & & & & & 2 & 0.02 \\
\hline Trachelas sp. 2 & & & & 1 & & & 1 & & 1 & & & 1 & 4 & 0.05 \\
\hline Trachelinae undet. & & 1 & & & & & & & & & & & 1 & 0.01 \\
\hline Trachelopachys cingulipes (Simon 1886) & 3 & & & & & & & & & & & & 3 & 0.03 \\
\hline Trachelopachys keyserlingi (Roewer, 1951) & & & & & & & & & & & 1 & 3 & 4 & 0.05 \\
\hline \multicolumn{15}{|l|}{ Tetragnathidae } \\
\hline Chrysometa aramba Levi, 1986 & & & & & & & & & & 1 & & & 1 & 0.01 \\
\hline Chrysometa boraceia Levi, 1986 & & 2 & & & 2 & & & & & & & & 4 & 0.05 \\
\hline Dolichognatha pinheiral Brescovit \& Cunha, 2001 & & & & 1 & 2 & & & & & & 1 & 1 & 5 & 0.06 \\
\hline Glenognatha lacteovittata (Mello-Leitão, 1944) & & & 1 & & & & & & & & & & 1 & 0.01 \\
\hline Leucauge roseosignata Mello-Leitão, 1943 & 1 & 15 & 2 & 4 & 7 & 8 & 2 & 1 & 2 & 1 & 2 & 1 & 46 & 0.52 \\
\hline Leucauge sp. 1 & & 8 & 1 & & 1 & & & & 1 & & & & 11 & 0.12 \\
\hline Leucauge sp. 2 & & & & & & & & & 1 & 2 & & 1 & 4 & 0.05 \\
\hline Leucauge sp. 3 & & & & & & & & & & 1 & & & 1 & 0.01 \\
\hline Lencauge sp. 4 & & & & & & & 1 & & & & & & 1 & 0.01 \\
\hline Leucauge sp. 5 & & & & & & & & & & 1 & & & 1 & 0.01 \\
\hline Leucauge volupis (Keyserling, 1893) & & & & & & & & & & 2 & 5 & & 7 & 0.08 \\
\hline Opas paranensis (Mello-Leitão, 1937) & & & & 1 & 1 & & & 4 & & 1 & 1 & 1 & 9 & 0.10 \\
\hline Tetragnatha longidens Mello-Leitão, 1945 & 5 & & & 20 & & & & & & 1 & & & 26 & 0.29 \\
\hline Tetragnatha sp. 1 & 1 & 1 & 2 & & & & & & & & & & 4 & 0.05 \\
\hline Tetragnatha sp. 2 & 1 & 1 & 6 & & & 1 & & & & & 2 & & 11 & 0.12 \\
\hline Tetragnatha sp. 3 & & 1 & & & & & 2 & & & 1 & & & 4 & 0.05 \\
\hline Tetragnatha sp. 4 & & & & 1 & & 1 & & & & & & & 2 & 0.02 \\
\hline Tetragnatha sp. 5 & & & & & & & & & & & 1 & & 1 & 0.01 \\
\hline Tetragnatha sp. 6 & & & & & & & 2 & & & & & & 2 & 0.02 \\
\hline Tetragnatha sp. 7 & & & & & & & & & & & & 2 & 2 & 0.02 \\
\hline Tetragnatha sp. 8 & & & & & & & 1 & & & & & & 1 & 0.01 \\
\hline \multicolumn{15}{|l|}{ Theridiidae } \\
\hline Anelosimus ethicus (Keyserling, 1884) & 5 & & 1 & & & 2 & & & & & & 1 & 9 & 0.10 \\
\hline Anelosimus nigrescens (Keyserling, 1884) & 1 & & 5 & & & 2 & & & & 1 & & 4 & 13 & 0.15 \\
\hline Anelosimus sp. & & & & & & 1 & & & & & & & 1 & 0.01 \\
\hline Argyrodes elevatus Taczanowski, 1873 & & & & & & & & & & & 1 & & 1 & 0.01 \\
\hline Ariamnes longissimus Keyserling, 1891 & & 2 & 2 & & 1 & 2 & 2 & 1 & & 4 & & 1 & 15 & 0.17 \\
\hline Chrosiothes niteroi Levi, 1964 & & 40 & 3 & & 1 & & & & & & & & 44 & 0.50 \\
\hline Chrosiothes perfidus Marques \& Buckup, 1997 & & 1 & & 6 & 2 & & & & & & & & 9 & 0.10 \\
\hline Chrysso compressa (Keyserling, 1884) & & & & & 1 & & & & & & & & 1 & 0.01 \\
\hline Chrysso nigrosterna Keyserling, 1891 & & 15 & & 1 & 3 & 13 & & 16 & 1 & 34 & 11 & 27 & 121 & 1.37 \\
\hline Chrysso rubrovittata (Keyserling, 1884) & & & 13 & 1 & & 1 & & & & & & & 15 & 0.17 \\
\hline Chrysso sp. 1 & & & & & & & & & & 14 & 16 & 1 & 31 & 0.35 \\
\hline Chrysso sp. 2 & & & & & & & & & & & & 1 & 1 & 0.01 \\
\hline Coleosoma sp. & & & & & & & & & 1 & & & & 1 & 0.01 \\
\hline Craspedisia cornuta (Keyserling, 1891) & & & & & & & & & 1 & & & & 1 & 0.01 \\
\hline Cryptachaea altiventer (Keyserling, 1884) & 7 & & 3 & 2 & 1 & 11 & 3 & 2 & 1 & 1 & & 9 & 40 & 0.45 \\
\hline Cryptachaea analista (Levi, 1963) & 1 & 1 & & 1 & & 4 & & & & & & & 7 & 0.08 \\
\hline Cryptachaea bellula (Keyserling, 1891) & & 1 & 13 & 2 & 1 & 2 & 1 & 2 & 1 & & & 1 & 24 & 0.27 \\
\hline Cryptachaea cinnabarina (Levi, 1963) & & & & 3 & 7 & 1 & & 1 & & & 1 & & 13 & 0.15 \\
\hline Cryptachaea digitus (Buckup \& Marques, 2006) & & & & & 1 & & & & & & & & 1 & 0.01 \\
\hline & & & & & & & & & & & & & & ontinu \\
\hline
\end{tabular}


Appendix 1. Continued.

\begin{tabular}{|c|c|c|c|c|c|c|c|c|c|c|c|c|c|c|}
\hline \multirow{3}{*}{ Taxa } & \multicolumn{12}{|c|}{ Riparian forests/microhabitats } & \multirow{3}{*}{ Total } & \multirow{3}{*}{$\%$} \\
\hline & \multicolumn{3}{|c|}{ Piratini } & \multicolumn{3}{|c|}{ Camaquã } & \multicolumn{3}{|c|}{ Sinos } & \multicolumn{3}{|c|}{ Maquiné } & & \\
\hline & RE & $\mathrm{FI}$ & GE & RE & $\mathrm{FI}$ & GE & RE & $\mathrm{FI}$ & $\mathrm{GE}$ & RE & $\mathrm{FI}$ & GE & & \\
\hline Cryptachaea hirta (Taczanowski, 1873) & 4 & & 3 & 1 & & 15 & 1 & & 5 & & & 7 & 36 & 0.41 \\
\hline Cryptachaea isana (Levi, 1963) & & & & 2 & & 9 & & & & & & & 11 & 0.12 \\
\hline Cryptachaea passiva (Keyserling, 1891) & 13 & 23 & 22 & 35 & 25 & 3 & 36 & 11 & 11 & 4 & 15 & 1 & 199 & 2.25 \\
\hline Cryptachaea rioensis (Levi, 1963) & & & & & & & & & & 1 & 3 & 1 & 5 & 0.06 \\
\hline Cryptachaea taim (Buckup \& Marques, 2006) & & & & 1 & 1 & 1 & & & & & & & 3 & 0.03 \\
\hline Cryptachaea triguttata (Keyserling, 1891) & & & & & 10 & 1 & 3 & 23 & 1 & 8 & 10 & & 56 & 0.63 \\
\hline Dipoena atlantica Chickering, 1943 & 1 & & 1 & & & & & & & & & & 2 & 0.02 \\
\hline Dipoena cordiformis Keyserling, 1886 & & & & & & & & & & & & 1 & 1 & 0.01 \\
\hline Dipoena ira Levi, 1963 & & & 5 & & & 2 & & 4 & & 4 & 6 & & 21 & 0.24 \\
\hline Dipoena pumicata (Keyserling, 1886) & & & 2 & 1 & & 1 & & & & & & 1 & 5 & 0.06 \\
\hline Dipoena pusilla (Keyserling, 1886) & & & & & & & & & 4 & & 2 & 1 & 7 & 0.08 \\
\hline Dipoena santacatarinae Levi, 1963 & & & & 9 & 23 & 5 & 36 & 24 & 12 & 13 & 2 & 5 & 129 & 1.46 \\
\hline Dipoena sp. 1 & 1 & & & 2 & 1 & 4 & 1 & 1 & & & & 1 & 11 & 0.12 \\
\hline Dipoena sp. 2 & & & & & & & & & & & 9 & & 9 & 0.10 \\
\hline Dipoena sp. 3 & & & & & & & & & & 3 & 1 & & 4 & 0.05 \\
\hline Dipoena sp. 4 & & & & 1 & & & & & & & & & 1 & 0.01 \\
\hline Dipoena taeniatipes Keyserling, 1891 & 1 & & & & & & 2 & & 1 & 2 & & 1 & 7 & 0.08 \\
\hline Dipoena variabilis (Keyserling, 1886) & & & & & & & & & & 2 & 3 & 1 & 6 & 0.07 \\
\hline Echinotheridion sp. & & & & & 2 & & & & & & & & 2 & 0.02 \\
\hline Emertonella taczanowskii (Keyserling, 1886) & & & 6 & & & & & & & & 1 & 17 & 24 & 0.27 \\
\hline Episinus teresopolis Levi, 1964 & & & & 5 & 5 & 45 & & & & & & & 55 & 0.62 \\
\hline Episinus sp. 1 & & & & & & & & & & 1 & & & 1 & 0.01 \\
\hline Episinus sp. 2 & 6 & 1 & 13 & & & & 5 & & 6 & & & & 31 & 0.35 \\
\hline Episinus sp. 3 & & & & & & & & & & 12 & 24 & 3 & 39 & 0.44 \\
\hline Exalbidion sp. & 6 & 2 & 23 & 4 & 4 & 5 & 5 & 1 & & 5 & 12 & & 67 & 0.76 \\
\hline Faiditus affinis (O.P.-Cambridge, 1880) & 4 & 43 & & 14 & 19 & 3 & 3 & 16 & & 3 & 2 & 1 & 108 & 1.22 \\
\hline Faiditus alticeps (Keyserling, 1891) & & & & & & & & 1 & & & & & 1 & 0.01 \\
\hline Faiditus americanus (Taczanowski, 1874) & 6 & & 4 & 1 & & & & & & & & & 11 & 0.12 \\
\hline Faiditus plaumanni (Exline \& Levi, 1962) & 5 & 2 & 17 & & & 1 & 8 & & & 3 & & & 36 & 0.41 \\
\hline Faiditus sicki (Exline \& Levi, 1962) & & & & & & & & 1 & & & & & 1 & 0.01 \\
\hline Faiditus striatus (Keyserling, 1891) & 3 & 35 & & 4 & 14 & 1 & & & & 5 & 22 & & 84 & 0.95 \\
\hline Faiditus sp. 1 & & & & 5 & 25 & 3 & & 8 & & 1 & & & 42 & 0.47 \\
\hline Faiditus sp. 2 & & & & & & & & 2 & & 2 & 3 & & 7 & 0.08 \\
\hline Faiditus sp. 3 & & & & & & & & & & & 1 & & 1 & 0.01 \\
\hline Faiditus sp. 4 & 1 & & & 1 & & & & & & & & & 2 & 0.02 \\
\hline Hadrotarsinae undet. & & & & & & & & & & & 1 & & 1 & 0.01 \\
\hline Hetschkia gracilis Keyserling, 1886 & & 22 & 9 & 20 & 54 & 62 & 3 & & & 29 & 77 & 24 & 300 & 3.39 \\
\hline Kochiura olaup (Levi, 1963) & 12 & 4 & 16 & 6 & 3 & 13 & 2 & & 2 & & 8 & 14 & 80 & 0.90 \\
\hline Neospintharus rioensis (Exline \& Levi, 1962) & 2 & 1 & 1 & & 1 & 2 & 1 & & 2 & & & & 10 & 0.11 \\
\hline Parasteatoda tesselata (Keyserling, 1884) & 5 & 1 & 12 & 1 & & & 7 & 1 & 15 & & & 1 & 43 & 0.49 \\
\hline Phoroncidia piratini Rodrigues \& Marques, 2010 & 1 & 1 & 2 & & & & & & & & & & 4 & 0.05 \\
\hline Phoroncidia reimoseri Levi, 1964 & & & & & 4 & 2 & 21 & 82 & 3 & 7 & 20 & & 139 & 1.57 \\
\hline Phoroncidia sp. 1 & & & & & & & & 1 & & & 1 & & 2 & 0.02 \\
\hline Phoroncidia sp. 2 & & 1 & 6 & & & & & & & & & & 7 & 0.08 \\
\hline Phycosoma alta (Keyserling, 1886) & 11 & & 54 & 6 & 27 & 22 & 21 & 51 & 7 & & & & 199 & 2.25 \\
\hline Rhomphaea Braziliensis Mello-Leitão, 1920 & 15 & 29 & 6 & 10 & 33 & 8 & & 2 & & 2 & 1 & & 106 & 1.20 \\
\hline Rhomphaea sp. 1 & & & & 1 & & 1 & & & & 2 & 1 & 1 & 6 & 0.07 \\
\hline Rhomphaea sp. 2 & & & & & & 1 & & & & & 1 & 3 & 5 & 0.06 \\
\hline Spintharus gracilis Keyserling, 1886 & & & & 3 & 3 & 3 & 26 & 29 & 44 & 89 & 111 & 17 & 325 & 3.67 \\
\hline Tekellina guaiba Marques \& Buckup, 1993 & 2 & 29 & 4 & 15 & 8 & 10 & 2 & 1 & & 8 & 18 & 3 & 100 & 1.13 \\
\hline Tekellina sp. 1 & 1 & & 1 & 4 & & & & 1 & & & & & 7 & 0.08 \\
\hline Tekellina sp. 2 & & & & & 1 & & & & & & & & 1 & 0.01 \\
\hline Theridiidae undet. & & & & & & & & & & 2 & & & 2 & 0.02 \\
\hline
\end{tabular}


Appendix 1. Continued.

\begin{tabular}{|c|c|c|c|c|c|c|c|c|c|c|c|c|c|c|}
\hline \multirow{3}{*}{ Taxa } & \multicolumn{12}{|c|}{ Riparian forests/microhabitats } & \multirow{3}{*}{ Total } & \multirow{3}{*}{$\%$} \\
\hline & \multicolumn{3}{|c|}{ Piratini } & \multicolumn{3}{|c|}{ Camaquã } & \multicolumn{3}{|c|}{ Sinos } & \multicolumn{3}{|c|}{ Maquiné } & & \\
\hline & $\mathrm{RE}$ & $\mathrm{FI}$ & GE & $\mathrm{RE}$ & $\mathrm{FI}$ & $\mathrm{GE}$ & $\mathrm{RE}$ & $\mathrm{FI}$ & GE & $\mathrm{RE}$ & $\mathrm{FI}$ & GE & & \\
\hline Theridion bergi Levi, 1963 & & & & & & 1 & & & & & & & 1 & 0.01 \\
\hline Theridion biezankoi Levi, 1963 & & 1 & & & & 6 & & & & & & 2 & 9 & 0.10 \\
\hline Theridion calcynatum Holmberg, 1876 & 31 & 50 & 51 & 30 & 19 & 17 & & & & & & & 198 & 2.24 \\
\hline Theridion eremum Levi, 1963 & & & & & & & & & & 1 & & & 1 & 0.01 \\
\hline Theridion filum Levi, 1963 & 1 & & & & & 7 & 8 & & 1 & & & & 17 & 0.19 \\
\hline Theridion opolon Levi, 1963 & & & 2 & & & & & 1 & & & & & 3 & 0.03 \\
\hline Theridion plaumanni Levi, 1963 & 11 & 3 & 56 & 17 & 3 & 20 & 3 & 3 & 18 & 2 & 20 & 22 & 178 & 2.01 \\
\hline Theridion positivum Chamberlin, 1924 & 30 & & 41 & 4 & 3 & 11 & 7 & & 7 & & & 3 & 106 & 1.20 \\
\hline Theridion quadripartitum Keyserling, 1891 & & & & & 10 & 7 & & & & 7 & 4 & & 28 & 0.32 \\
\hline Theridion striatum Keyserling, 1884 & & & & 1 & 1 & 6 & & & & & & & 8 & 0.09 \\
\hline Theridion teresae Levi, 1963 & & & & 16 & 36 & 12 & & & & 5 & 16 & 3 & 88 & 0.99 \\
\hline Theridion tinctorium Keyserling, 1891 & 9 & & 7 & & & 1 & & & & & & & 17 & 0.19 \\
\hline Theridion sp. 1 & 2 & 1 & 2 & 15 & 2 & 2 & & & & & & 2 & 26 & 0.29 \\
\hline Theridion sp. 2 & & 1 & & & & & & & & & & & 1 & 0.01 \\
\hline Theridion sp. 3 & 1 & & & & & & & & & & & & 1 & 0.01 \\
\hline Theridula gonygaster (Simon, 1873) & & & & & & & & & & & & 1 & 1 & 0.01 \\
\hline Thwaitesia affinis O.P.-Cambridge, 1882 & & & & & & & & 2 & & 20 & 31 & 4 & 57 & 0.64 \\
\hline Thymoites promatensis Lise \& Silva, 2009 & 2 & 2 & 9 & 5 & 112 & 18 & 10 & 272 & 6 & & & & 436 & 4.93 \\
\hline Thymoites sp. 1 & 14 & 1 & 26 & & & 4 & & 1 & & & & & 46 & 0.52 \\
\hline Thymoites sp. 2 & & & & 1 & & & & & & & & & 1 & 0.01 \\
\hline Thymoites sp. 3 & 18 & & 3 & & & 1 & 11 & & & & & & 33 & 0.37 \\
\hline Thymoites sp. 4 & & & & & & & & & & 13 & 2 & 8 & 23 & 0.26 \\
\hline Thymoites sp. 5 & 2 & 1 & 2 & & & & & & & & & & 5 & 0.06 \\
\hline Thymoites cristal Rodrigues \& Brescovit, 2015 & & & & & 1 & 1 & & & & & & & 2 & 0.02 \\
\hline Thymoites camaqua Rodrigues \& Brescovit, 2015 & & & & 2 & & & & & & & & & 2 & 0.02 \\
\hline Tidarrem haemorrhoidale (Bertkau, 1880) & 3 & 5 & & & 6 & & 3 & 8 & 1 & 1 & 4 & 1 & 32 & 0.36 \\
\hline Wamba congener O.P.-Cambridge, 1896 & 14 & 7 & 15 & 7 & 2 & 5 & & & & & 1 & 4 & 55 & 0.62 \\
\hline Wamba crispulus (Simon, 1895) & 13 & 45 & 71 & 46 & 27 & 26 & 18 & 8 & 4 & 6 & & 4 & 268 & 3.03 \\
\hline Wirada sp. 1 & & & & 2 & & & & & & 1 & 1 & & 4 & 0.05 \\
\hline Wirada sp. 2 & & & & 2 & 3 & & & & 1 & & & & 6 & 0.07 \\
\hline \multicolumn{15}{|l|}{ Theridiosomatidae } \\
\hline Chthonos sp. 1 & & & & & & & & 6 & & 1 & 4 & & 11 & 0.12 \\
\hline Chthonos sp. 2 & & & & & & & & & & & 1 & & 1 & 0.01 \\
\hline Chthonos sp. 3 & & & & & & 1 & & & & & & & 1 & 0.01 \\
\hline Naatlo sp. 1 & & & & & & & & & & 9 & 2 & 2 & 13 & 0.15 \\
\hline Naatlo sp. 2 & 1 & & & & & & & & & & & & 1 & 0.01 \\
\hline Naatlo sp. 3 & & & & & & & & & & 1 & & & 1 & 0.01 \\
\hline Theridiosoma chiripa Rodrigues \& Ott, 2005 & & 1 & & & & & & & & 1 & & & 2 & 0.02 \\
\hline Theridiosoma sp. 1 & & & & 2 & & & & & & & & & 2 & 0.02 \\
\hline Theridiosoma sp. 2 & & & & & & & & & & & 1 & & 1 & 0.01 \\
\hline Theridiosoma sp. 3 & & 1 & & & & & & & & & & & 1 & 0.01 \\
\hline Theridiosomatidae undet. & & & & & 3 & & & & & & & & 3 & 0.03 \\
\hline Wendilgarda sp. 1 & & 4 & & 2 & 37 & 12 & 1 & 10 & 1 & 7 & & 2 & 76 & 0.86 \\
\hline Wendilgarda sp. 2 & & 13 & & & & & & & & & & & 13 & 0.15 \\
\hline \multicolumn{15}{|l|}{ Thomisidae } \\
\hline Epicadinus sp. 1 & & & & & 1 & & & & & & 1 & & 2 & 0.02 \\
\hline Epicadinus sp. 2 & & & & & & & & & & & 1 & & 1 & 0.01 \\
\hline Epicadus heterogaster (Guérin, 1829) & & & & & & & & & & & & 1 & 1 & 0.01 \\
\hline Misumenoides sp. & & & & & & 1 & & & & & & & 1 & 0.01 \\
\hline Misumenops maculissparsus Keyserling, 1891 & & & & & & & & & 1 & & & & 1 & 0.01 \\
\hline Misumenops pallens (Keyserling, 1880) & & & 2 & 1 & & 1 & 1 & & & & & 1 & 6 & 0.07 \\
\hline Misumenops sp. 1 & & & & & & & & & & 1 & & & 1 & 0.01 \\
\hline Misumenops sp. 2 & & & 3 & & & 1 & & & & & & & 4 & 0.05 \\
\hline
\end{tabular}


Appendix 1. Continued.

\begin{tabular}{|c|c|c|c|c|c|c|c|c|c|c|c|c|c|c|}
\hline \multirow{3}{*}{ Taxa } & \multicolumn{12}{|c|}{ Riparian forests/microhabitats } & \multirow{3}{*}{ Total } & \multirow{3}{*}{$\%$} \\
\hline & \multicolumn{3}{|c|}{ Piratini } & \multicolumn{3}{|c|}{ Camaquã } & \multicolumn{3}{|c|}{ Sinos } & \multicolumn{3}{|c|}{ Maquiné } & & \\
\hline & RE & $\mathrm{FI}$ & GE & RE & $\mathrm{FI}$ & GE & RE & $\mathrm{FI}$ & GE & RE & $\mathrm{FI}$ & GE & & \\
\hline Misumenops sp. 3 & 1 & & & 1 & & 4 & & & 1 & & & 1 & 8 & 0.09 \\
\hline Misumenops sp. 4 & & & & & & & & & & & & 1 & 1 & 0.01 \\
\hline Misumenops sp. 5 & & & & & & & & & & & & 1 & 1 & 0.01 \\
\hline Onocolus infelix Mello-Leitão, 1941 & & & & & 6 & & & 7 & & & & & 13 & 0.15 \\
\hline Onocolus intermedius (Mello-Leitão, 1929) & 1 & & & 2 & 1 & 3 & 5 & 1 & 3 & & & & 16 & 0.18 \\
\hline Onocolus sp. 1 & & & & & & & 1 & & & 1 & & 3 & 5 & 0.06 \\
\hline Onocolus sp. 2 & & & & 1 & 1 & 3 & 1 & 1 & & 1 & & & 8 & 0.09 \\
\hline Runcinioides argenteus Mello-Leitão, 1929 & & & & & & & & & & & & 2 & 2 & 0.02 \\
\hline Sidymella longispina (Mello-Leitão, 1943) & & & & & 2 & & & & & 1 & & & 3 & 0.03 \\
\hline Sidymella lucida (Keyserling, 1880) & 1 & & & & & & & & & & & & 1 & 0.01 \\
\hline Sidymella multispinulosa (Mello-Leitão, 1944) & & & & 1 & & 1 & & & 1 & & & & 3 & 0.03 \\
\hline Stephanopis colatinae Soares \& Soares, 1946 & & & & & & & & & & 1 & 2 & & 3 & 0.03 \\
\hline Synema nigrianum Mello-Leitão, 1929 & & & & & 1 & & & & & & & & 1 & 0.01 \\
\hline Thomisidae undet. 1 & & 2 & & & & 1 & & & & & & & 3 & 0.03 \\
\hline Thomisidae undet. 2 & & & & 6 & 1 & 1 & & & & & & & 8 & 0.09 \\
\hline Thomisidae undet. 3 & & & & & & & & & & 1 & & & 1 & 0.01 \\
\hline Thomisinae undet. & & & & & 1 & 8 & & & & 1 & & & 10 & 0.11 \\
\hline Tmarus elongatus Mello-Leitão, 1929 & & & & & & & & & & & 1 & & 1 & 0.01 \\
\hline Tmarus polyandrus Mello-Leitão, 1929 & 9 & 7 & 7 & 4 & 16 & 3 & 2 & 1 & 1 & 1 & & & 51 & 0.58 \\
\hline Tmarus pugnax Mello-Leitão, 1929 & 7 & 6 & 4 & & 4 & 1 & 2 & 2 & & & & & 26 & 0.29 \\
\hline Tmarus striolatus Mello-Leitão, 1929 & & & & & 1 & & 1 & 1 & 1 & & & & 4 & 0.05 \\
\hline Tmarus sp. 1 & & & & & & & & 1 & 1 & & & & 2 & 0.02 \\
\hline Tmarus sp. 2 & 1 & & 1 & & 4 & 2 & 2 & & & 3 & 5 & & 18 & 0.20 \\
\hline Tmarus sp. 3 & & & 4 & & & & & & & & & & 4 & 0.05 \\
\hline Tmarus sp. 4 & & & 4 & 1 & & & & & & & & & 5 & 0.06 \\
\hline Tmarus sp. 5 & 1 & & & & & & & & & & & & 1 & 0.01 \\
\hline Tmarus sp. 6 & 8 & 2 & 7 & 5 & 2 & 5 & & & & & & & 29 & 0.33 \\
\hline Tmarus sp. 7 & & & 1 & & & & & & & & & & 1 & 0.01 \\
\hline Tmarus sp. 8 & & & 1 & & & & & & & & & & 1 & 0.01 \\
\hline Tmarus sp. 9 & & & & & 1 & & & & & & 1 & & 2 & 0.02 \\
\hline Tmarus sp. 10 & 2 & 1 & & & & & & & & & & & 3 & 0.03 \\
\hline Tmarus sp. 11 & & & & & & & & 1 & & & & & 1 & 0.01 \\
\hline Tmarus sp. 12 & & & & & & 1 & & & & & & & 1 & 0.01 \\
\hline Tmarus sp. 13 & & & & & & & 1 & & & & & & 1 & 0.01 \\
\hline Tmarus sp. 14 & & & & & & & & & & 1 & & & 1 & 0.01 \\
\hline Tmarus sp. 15 & & & & & & & & & & & & 1 & 1 & 0.01 \\
\hline Tmarus sp. 16 & 1 & & 1 & & & & 1 & & & 3 & 1 & 1 & 8 & 0.09 \\
\hline \multicolumn{15}{|l|}{ Uloboridae } \\
\hline Conifaber yasi Grismado, 2004 & & & & 1 & & & 18 & 7 & & 12 & 5 & & 43 & 0.49 \\
\hline Miagrammopes sp. 1 & 6 & 45 & & 7 & 22 & & 12 & 23 & 2 & 9 & 12 & 2 & 140 & 1.58 \\
\hline Miagrammopes sp. 2 & & & & & & & & & & & 1 & & 1 & 0.01 \\
\hline Miagrammopes sp. 3 & & & 1 & & & & & & & & & & 1 & 0.01 \\
\hline Miagrammopes sp. 4 & & & & & & & 1 & & & & & & 1 & 0.01 \\
\hline Philoponella gr. fasciata & & & & & & & & & & 3 & 9 & & 12 & 0.14 \\
\hline Uloborus sp. 1 & 1 & & & & & & 2 & 6 & 2 & & & & 11 & 0.12 \\
\hline Uloborus sp. 2 & & & & & & & 1 & & & & & 1 & 2 & 0.02 \\
\hline Uloborus sp. 3 & & & 1 & & & & 2 & 1 & & & & & 4 & 0.05 \\
\hline Total individuals & 536 & 720 & 760 & 540 & 961 & 642 & 457 & 846 & 328 & 885 & 1467 & 709 & 8851 & 100 \\
\hline Total species & 116 & 97 & 118 & 113 & 126 & 139 & 105 & 88 & 101 & 115 & 112 & 120 & & \\
\hline Total individuals (riparian forest) & & 2016 & & & 2143 & & & 1631 & & & 3061 & & & \\
\hline
\end{tabular}

